\title{
Effects of Macroeconomic Variables on the Stock Market Volatility: The Pakistan Experience
}

\author{
Waqar Khalid ${ }^{1, *}$, Saifullah Khan ${ }^{1,2}$ \\ ${ }^{1}$ School of Economics, Quaid-I-Azam University, Islamabad, Pakistan \\ ${ }^{2}$ Department of Management Sciences, University of Swabi, Khyber PakhtunKhwa, Pakistan \\ *Corresponding author: waqarkhalidicp@yahoo.com
}

\begin{abstract}
This research paper empirically investigates the effects of interest rates, exchange rates and inflation rates on stock market performance of Pakistan by using annual time series data covering the 1991-2017 periods. The prime intention of this research was to inspect the long-run and short-run relationships between the KSE-100 index and macroeconomic variables by employing the econometric techniques of Autoregressive Distributed Lag (ARDL) bounds testing procedure to cointegration and the Error Correction Model (ECM), respectively. By applying the ARDL model, the empirical results revealed the fact that there was a negative and significant impact of interest rate on the market index, whereas; the exchange rate and the inflation rate have a positive impact on stock market volatility in the long-run. Furthermore, the ECM analysis pointed out that an estimated coefficient of the error correction term was significant with expected negative sign and showed that $46.53 \%$ deviation of the stock market index are corrected in the short-run per year. The study recommended that the monetary authorities should further reduce the bank rate up to the lowest rate in order to stimulate the stock market performance, which in turn; will boost the existing investment level and will encourage the new investment into the stock market. In addition, this policy will also ensure in the reduction of higher inflation rates. And the study found that the reduction in bank rate and stabilization in exchange rate is essential to local and foreign investors in the short-run.
\end{abstract}

Keywords: stock exchange, ARDL, Error Correction, macroeconomic variables, time series data, KSE-100 index, Pakistan

JEL Codes: E31, E43, F31

Cite This Article: Waqar Khalid, and Saifullah Khan, "Effects of Macroeconomic Variables on the Stock Market Volatility: The Pakistan Experience." International Journal of Econometrics and Financial Management, vol. 5, no. 2 (2017): 42-59. doi: 10.12691/ijefm-5-2-4.

\section{Introduction}

\subsection{Background of the Study}

A well-functioning and a well-developed financial sector play a leading role in the economic growth and development of a country. The efficient and effective utilization of capital resources in the financial market is the imperative job of a well-organized financial system. Through the financial system, the economy's scarce resources move from savers to borrowers. Savers provide their surplus income to the financial system with the expectations to achieve the highest rate of return in future. Conversely, borrowers demand funds from the same system with the idea that they will be mandatory to repay the amount with the interest rate in future.

The financial system of a country has two main classes, (1) Financial Markets, and (2) Financial Intermediary. Financial markets are the institutions and arrangements which brings together buyers and sellers of financial instrument. The elementary function of a financial market is the proper allocation of savings of individuals eventually in the economy. That is, to collect funds from a saving surplus unit and invest that into a saving deficit unit. In Pakistan, the bond or security market and the stock market are the principal financial markets. In contrast, financial intermediaries consist on those financial arrangements and institutions through which lenders can indirectly offer finances to debtors. Financial intermediaries include the overall banking sector of Pakistan. These are the banks through which the money flows from the hands of savers to borrowers.

Financial markets have two main categories, (i) Money market, and (ii) Capital market. Money markets are those institutions which are concerned with transactions of short-term credit instruments (the maturity time of such instruments is less than a year), for example, bonds and treasury bills, etc. This market has no physical existence found anywhere like the stock market, but it refers the network of all demanders, suppliers and brokers of short-term bonds or treasury bills extend to the whole country. On the contrary, capital markets refer those institutions where longer-term financial securities (the maturity time is more than a year) are traded [1], for instance, stocks, bonds, shares, etc. This market structure includes those financial institutions through which surplus 
money (savings) in the economy is transmitted to investors. The major components of capital market comprise of insurance companies, investment banks, savings banks, stock exchanges, etcetera.

A vibrant, developed and dynamic capital market can present appreciably in the rapid economic growth of a country. Due to the well-functioning of a capital market, the funds raised from people can easily mobilize for further investments to others in the productive channels, therefore activates the unused monetary resources. It also assists in capital formation, which refers the net accumulation to the existing quantity of stock of capital in the country. Through the mobilization of such funds, it generates savings, which in turn, available in different sectors of the economy such as agriculture and industry. In Pakistan, the capital market consists of the stock market or equity market and debt market.

Based on the latest economic facts, Pakistan is considered an emerging global economy. The economic outcome depends on two most important factors; (i) the consistent political and macroeconomic stability on national levels, which provokes investor's confidence and create a center of attention for home and abroad capital, plus (ii) the current financial sector development and revolution. From the observation of emerging Asia, one of the changes such as the structural changes in the equity market has been noteworthy [2].

The equity market is chief in establishing the speed with which policy steps changes are spread out into the whole country. This market is really sensitive to the changes in monetary policy tools through their handlings of the levels of macroeconomic variables in the country. The stock market performance is one of the leading dynamics which affects the economic progress of a nation and may have practical implications for macroeconomic variables to accomplish the preferred outcomes. This market performance is highly influenced by many macro variables, for instance, interest rate, exchange rate and inflation rate [3]. The stock market development level, domestic currency value and the interest rate level give details of the dynamics in the development level of an economy [69].

The finance theory suggests that there is a relationship among these variables both in the short and long run. For instance, if the central bank increases the interest rate from its previous level, this policy step would clue investors to find the money market for their investments, if other variables do not change. Conversely, if the interest rate decreases by the central bank from its prior level, this change would be a signal for investors to mobilize their funds into the stock markets giving a better reward. But this move in investments is possible only if both the prescribed markets are perfectly close substitutes to each other in the long-run. A negative and significant relation between interest rate and stock return has been found in the study conducted by Ahmad et al. [4]. Similarly, the interest rate shows a negative and significant relationship with the stock prices in the long-run [5].

There are a wide range of economic factors which can influence the behavior of stock market volatility, but the most important among all the factors is the exchange rates which have attracted the attention of not only economists and policymakers, but the investment community as well for a long time [6]. The exchange rates develop the underlying stock market performance [7]. The disorder in equity markets can be prohibited from maintaining a proper check on the existing exchange rates. Then again, if stock prices influence the exchange rates of a country, in that case steps may be implemented to regularize the normal workings of stock markets. Depreciation of currency in a country increases those firms competitiveness that are involved in export business because the price of such stocks will pursue a rising trend and the anticipation is that overseas investors are attracted to the domestic stock market. The exchange rate has a constructive influence on the stock return in the long term [5] and significant relation has been concluded for the same variables in the study conducted by [4]. Though, Aslam [8] put forward that the correlation between stock market performance and the domestic currency is negative. Whereas, the empirical study taken by Ihsan et al. [9] revealed no evidence for association between Fx rate and the market index for Pakistan.

Since the independence of Pakistan, the Pakistan's currency (PKR) remained related to the Pound Sterling up to the month of September, 1971 and afterwards to the United States dollar (USD) till January, 1982 under the fixed exchange rate system [10]. But this arrangement was changed to the managed floating exchange rate system with effect from January 8, 1982 by the government of General Zia-ul-Haq with the aim of sustaining a favourable balance of payment and to ensure export competitiveness [10]. Under this system, the PKR value was settled on a daily basis relating to a basket of currencies of Pakistan's key trading competitors and partners. Afterwards, when Pakistan becomes the $7^{\text {th }}$ atomic power of the globe and successfully conduct nuclear detonation on May 8, 1998, then several economic sanctions were imposed on our homeland by its foremost donors. Due to such reasons, the foreign exchange reserves of Pakistan fall sharply. After such nuclear explosions, a two-tier or dual exchange rate regime (i-e. official exchange rate and floating interbank exchange rate) were launched with effect from July 22, 1998. Nevertheless, effective from May 19, 1999, the exchange regime has been integrated, and the market-based floating exchange rate system was introduced. Under this system, the currency rate is determined by the Dd-Ss forces in the Fx market. At present, Pakistan is prevailing floating rate, where each commercial bank sets its personal exchange rates based on its time spanning positions. The State Bank of Pakistan started making purchases in unofficial markets to divert the flow of foreign exchange from unofficial markets to interbank markets [11]. While effective from July 20, 2000 to now, Pakistan has adopted the free floating regime of exchange rate. Under this regime, the currency rate is decided by the interactions of free market forces of demand and supply in an open market, and hence there is no role of the State Bank of Pakistan (SBP) [10].

The theoretical relationship between inflation rate and stock market performance has been empirically investigated by many financial economists across the globe. When the overall price level rises in the economy, each currency unit buys fewer commodities, so reducing the purchasing power of money income. The social effects of an inflationary trend of an economy are frequent and may be negative or positive, but largely negative [12]. An 
unfavorable social cost of an anticipated inflation contains a fall in the real money value and other monetary articles over a long time span. The unanticipated inflation may dampen savings and investments, and also hurts citizens on fixed pensions. Likewise, if the inflation rate is very fast, scarcity of products occurs in the market as households start hoarding due to which prices will begin to rise even more in the future times. More specifically, the stock prices determine how efficient and effective the equity market distributes shares and equities on the ground of inclination as well as the availability of market information. Rise or fall in the price of stock builds ambiguity and uncertainty for those people who plan to invest and, in a result, affect the demand and supply forces of stocks. Consequently, rises in the general prices may influence the investment decision of a potential investor which has an adverse impact on the overall returns of stocks in the stock market at large.

The economy of Pakistan is one of the essential regional economies. Though, uncertainty in the shape of wars, earthquakes, floods, shocks, etc. and frequent political instability has badly affected the economic performance of the economy in question over the last two to three decades. But no one can deny the fact that the Pakistan economy has tremendous capacity to achieve high levels of economic efficiency by way of equivalent development in major sectors. The verdicts may too be noticed on the currency, which has largely depreciated against the foreign currencies by a large margin in recent times with immediate effects on macroeconomic indicators used to assess the economic position and the market index is certainly one of them.

The present democratic government, which was elected in 2013 with the majority public mandate has dedicated serious efforts to reform and in this respect, certain measures have been in action to stop the continuous declining rate of PKR/US\$ and encourage steps helpful to equity market development. Despite the pluses and minuses of the current government interest, to a degree the currency value has appreciated against the USD for a shorter time, but the major confront is whether a targeted point of currency parity will be sustained in the presence of the immense challenges facing the economy of Pakistan today. And more essentially, the interlinked macroeconomic effects may be checked on the stock market index, which is an eminent indicator and the investors use it as a yardstick to invest their past and current savings in the stock market. This research study is also an endeavor to empirically consider the effects of macroeconomic variables on the stock market volatility as measured by the Karachi Stock Exchange (KSE-100) index. The empirical relations of these variables may present an idea to stock market investors living anywhere and acts as a knowledge base for financial experts and concerned government bodies to make profitable decisions which develop the significance of the current empirical work.

\subsection{Karachi Stock Exchange (KSE-100) Index}

In this research work, we are going to examine the short and long term connection of macro variables on the equity market performance by applying yearly dataset covering the 1991-2017 periods. On September 18, 1947, the Karachi Stock Exchange (KSE) was introduced which was initially considered the biggest stock exchange in the region on the basis of market capitalization indicator. At the start, a total number of five companies were registered and the KSE-50 index was set up to capture its performance, which was based on 50 financial companies, and with times more companies were appearing in the list of the KSE due to the enhancement of trading activities in volume. Hence, to better capture the stock market performance, the KSE-50 index was changed into the PSX index in November 1991 with a reference value of 1000 . The KSE-100 indicator consists of top hundred listed firms selected from different sectors in terms of highest market capitalization. There are many indices that are used in Pakistan for measuring the stock market volatility such as the KSE-30, KSE-50, LSE 25, ISE 10, BR Index 30 , BR Index 100, KMI 30 etc., but the most frequently quoted index is the KSE-100; as it offers an excellent indication of how the Pakistan stock market is performing. It is the biggest market index, which represents the sector-wise (34) performance of the biggest companies of Pakistan listed on the exchange market and works as a yardstick to evaluate stock prices. The KSE-100 index captures about $90 \%$ of the market capitalization of listed companies [9]. It is a value weighted index and is constituted after every six months. The same index was renewed as a free float index on October 15, 2012 and in the same year, the KSE was acknowledged as the best performing stock market globally. On March 6, 2015, there were 580 companies on the KSE with entire market capitalization of 7, 625.837 billion rupees [13].

With effect from 11 January, 2016, all the three equity markets ${ }^{1}$ were integrated into one equity market, commonly known as the Pakistan Stock Exchange (PSX) which provides a sole platform to foreign investors mostly. Latest statistics show that the PSX-100 index (or the KSE-100 index) was a top ranked market in South Asia and stood in $5^{\text {th }}$ position as a finest performing stock market across the boundaries in 2016 by Bloomberg, providing a total return of $46 \%$ for the same year. And this return was also stood best in $\mathrm{MSCI}^{2}$ frontier markets. Over the last 10 years, the average gain of the PSX was $20 \%$ and over the last 20 years, this return was $24 \%$. The same index gained a huge momentum in the fiscal year 2016 . During the first quarter of the financial year 2016, the PSX index showed a sluggish and sliding trend because of low oil prices in the market. But during the 2016Q2, the stock market gained an upward trend and business investors remained confident and bullish even with tensions in political plus international boarder fronts. Some of the sectors which have contributed to the PSX index include banking, refinery, pharmaceutical, cement, E \& P, and so on. Starting from July 1, 2016 up to May 8, 2017, the covered time span witnessed an upward trend for the market index. The KSE-100 index showed marvelous performance of the PSX market over the stated period largely because of reforms undertaken by $\mathrm{SECP}^{3}$,

${ }^{1}$ Karachi, Lahore and Islamabad

${ }^{2}$ MSCI stands for Morgan Stanley Capital International

${ }^{3}$ SECP stands for Securities and Exchange Commission of Pakistan 
better macroeconomic indicators, improved security conditions, and the rest. On June 30, 2016, level of the PSX-100 index was at $37,783.54$ achieved 13,152 points and on May 8, 2017, level of the same index remained at $50,935.91$ which show a growth of $34.8 \%$. During the budget year $2017^{4}$, the PSX index gained its peak point at 50, 935.91 on May 8, 2017 while, the lowest point of the same index was at $37,966.76$ on July 4, 2016. Furthermore, the average daily volume of 379.1 million shares was witnessed during July 2016 to March 2017 which shows a three times increase as compare to previous periods [13]. The Table 1 presents the summary of the latest statistics on the PSX market over the last few years.

\subsection{Problem Statement}

The stock market volatility and its impact on the macro economy is the core interest area of research for economists, policymakers, financial analysts and business community experts due to its crucial role in the economic development of a country. The finance theory suggests that variation of the stock market is extensively correlated with different macroeconomic variables. Among the class of those macroeconomic variables, the fluctuations in both interest rate and exchange rate are considered to be major variables which can exert a momentous influence on the stock market volatility. A change in interest rate is an essential economic and financial factor influencing the value of stocks and stock market return [14]. The converse relationship of interest rate with exchange rate can force the value of stock in either direction. Alternatively, the level of inflation appears to affect the price of common stocks, but the relation between the two variables is unclear. Some research studies like Schwert [15] and Fama [16] established a converse and significant association between inflation and the equity market. Though, some empirical works such as Pearce and Roley [17] and Hardouvelis [18] established no such type of relations between the said variables. And the same kind of contradiction has also been found in the relationship between exchange rate and the stock market index.

Irrespective of the theoretical knowledge and the significance of the relationship between stock market volatility and macroeconomic factors, the empirical evidence suggests that there exists a clear dichotomy about the relationships between stock market return and macroeconomic variables. Minuscule idea about the actual relationship of interest rate and exchange rate with stock market volatility is one of the main issues of investors, which can adversely affect their future profitability. Since the association between stock market return and macroeconomic factors is not obvious, it is obligatory for researchers to explore the existing behaviour of the variables. But surprisingly, a dearth of empirical studies exists in Pakistan to explore the interactions between stock market volatility and macroeconomic variables. Though some research studies are available on the same concern, but mostly they have investigated the interactions between exchange rate and the KSE-100 index. Therefore, this research study is an endeavour to fill the empirical research gap and to investigate the short-run and long-run relationship of the stock market volatility with macroeconomic variables. To my knowledge, this study is the opening of its nature at the countrywide level of Pakistan since the Asian crisis of 1997-98.

\subsection{Research Questions}

Following are the few major research questions that we are going to address in this research study.

(1) Is interest rate and exchange rate having a relationship with stock market performance of Pakistan?

(2) Does inflation rate affect stock market performance in Pakistan?

(3) Is there any long term correlation exist between equity market volatility and macroeconomic variables in Pakistan?

\subsection{Research Objectives}

Below are the main objectives of this research paper:

(1) To empirically investigate the effects of interest rate and exchange rate changes on the equity market volatility of Pakistan Stock Exchange both in the short-run and long-run periods.

(2) To find out whether the KSE-100 index in Pakistan is significantly influenced by inflation rate or not, both in the short-run and long-run in a time series arrangement.

(3) To explore whether there exist a long term relationships between the KSE-100 index and macroeconomic variables or not.

(4) To detect the difference in short-run and long-run relationship of these macroeconomic variables on the KSE-100 index of the Pakistan Stock Exchange.

After this introduction chapter, the remainder of the paper will proceed as follows. Section 2 reviews the existing literature on the study. Section 3 presents a detailed description of the data and data sources. Section 4 deals with the theoretical and empirical framework, including the ARDL estimation strategy. Empirical results of the study are discussed in Section 5. Lastly, Section 6 concludes this study with some policy implications.

\section{Literature Review}

An extensive number of research articles can be found worldwide examining the relationship between stock market volatility and macroeconomic variables over the last half century. The economic and financial theory conceived that there is a possible and mixed association found between the stock market and macroeconomic variables. In recent times, a large number of empirical works focus on the dynamic relations between the stock market and interest rate and exchange rate. 
Table 1. Profile of Pakistan Stock Exchange (PSX)

\begin{tabular}{|l|c|c|c|c|c|}
\hline Description & $2012 / 13$ & $2013 / 14$ & $2014 / 15$ & $2015 / 16$ & $2016 / 17^{*}$ \\
\hline Total Listed Companies & 569 & 557 & 560 & 560 & 560 \\
\hline New Companies Listed & 4 & 5 & 9 & 6 & 4 \\
\hline Funds Mobilized (Rs. in billion) & 29.5 & 47.6 & 79.6 & 111.2 & 21.9 \\
\hline Total Listed Capital (Rs. million) & $1,116,005.0$ & $1,100,304.9$ & $1,189,518.9$ & $1,289,081.0$ & $1,297,159.0$ \\
\hline Market Capitalization (Rs. million) & $5,154,738.0$ & $6,655,294.8$ & $7,421,031.6$ & $7,588,472.2$ & $9,594,805.0$ \\
\hline Total Shares Volume (million) & $54,319.0$ & $56,580.6$ & $64,617.2$ & $55,430.3$ & $70,518.6$ \\
\hline Average daily shares volume (m) & 221.0 & 229.1 & 261.0 & 220.8 & 379.1 \\
\hline *end March, 2017 & & & & \\
\end{tabular}

Source: Pakistan Stock Exchange.

The earlier studies such as Modigliani [19] and Mishkin [20] conclude that smaller interest rate rise stock prices which sequentially lead to improved business investment activity. In general, a small interest rate directs privileged capital flows to the equity market in anticipation for a higher profit where a high rate of interest endorses more saving amounts in banking sector and accordingly lessens the capital flow to the open stock markets. The empirical study conducted by Fama and Schwert [21] concludes an inverse relationship between stock returns and T-bills rates. Mukit [5] investigated the effects of interest rate changes on the stock market return by using annual time series data from 1991 to 2012. The Johansen cointegration procedure demonstrates that the interest rate shows a negative and significant relationship with the stock prices in the long-run and also there exist at least one cointegrating relation between the variables. The Granger causality test shows that there exists a unidirectional causality from interest rates to stock prices.

A recent dynamic study analyzed by Mukit [22] examines the economic effects of interest rates on stock market volatility by employing monthly data over the period of 1991 to 2012 for the Bangladesh's economy. A cointegrating test exposes a significant and stable long-run connection between the selected variables. It has also been concluded that a $1 \%$ rise in interest rate causes a $13.20 \%$ reduction in market index in the long-run. The ECT coefficient value shows that $0.12 \%$ variation of stock returns is corrected in the short term. The result of the impulse response function also confirms the converse relationship between the variables included in the model. And, the result of the Granger causality affirms the existence of a unidirectional causal relationship which is from the interest rate to stock market index.

There have been a large number of research studies investigating the dynamic and causal relationship between exchange rates and stock market volatility and all these empirical studies provide mixed results about the relationship between the two variables. Kasman [23] analyzed the linkage between exchange rate and stock prices for the stock market of Turkey by using a high frequency data. The numerical results of Johansen approach provide empirical evidence that a long term connection exist between stock prices and exchange rate. What's more, the findings of the Granger causality analysis signify a unidirectional causal relationship between the two variables and hence, the causality relation exists from the exchange rate to industry sector index. For the stock market of India, Nath and Samanta [24] have inspected the dynamic and causal relationship of the exchange rate with stock market return by using daily time series data covering the periods of March 1993 to December 2003. The outcomes prove that the casual linkage between the two markets is commonly absent, however, in recent periods, a strong causal relationship has been found from stock market return to foreign exchange market return. Similarly, Kutty [6] studied the empirical relationship of the exchange rate with stock prices for the Mexican's stock market while using the weekly data for the year of Jan-1989 to Dec-2006. The results of cointegration test presents that there is no long time correlation exists between the examined data. While the Granger causality test recommends for the short-run relationship between the explored data.

A same kind of analysis has been carried out by Ihsan et al. [9] in Pakistan and checked for the relationship between exchange rate and stock market index. Considering the daily time series data over the period of September 2012 to May 2014, the results of the Johansen technique to cointegration report that there is no long-run involvement exists between currency rate and KSE-100 index. Whereas, the Granger causality test concludes that the currency rate doesn't cause the PSX index. Employing the GARCH model, Mlambo et al. [25] assessed the economic effects of exchange rate changes on the stock exchange of Johannesburg (JSE) by using monthly South African dataset over the 2000-2010 periods. After estimating the model, they found a very weak linkage between exchange rate changes and the JSE market. Further, the impact of prime overdraft rate plus total mining production on the market capitalization was found negative. But surprisingly, the impact of interest rate of US on the market capitalization was found positive. It was suggested that government should focus exchange rate as a policy instrument to magnetize foreign portfolio investment. Using the ARCH family and Johansen cointegration models, Bhat and Shah [26] investigated the relationship between stock market volatility and changes in exchange rate for Pakistan using a weekly time series for the 1997-2013 periods. The results of Johansen cointegration model conclude that both the examined variables are cointegrated with each other in the long-run. And the Granger causality verdicts confirm the bi-directional 
causal relationship between the two variables under examination.

A more recent study on the same concern carried out by Poornima and Ganeshwari [27] tried to look at the dynamic attachment between NIFTY index and exchange rate by applying the data periods from July 2014 to July 2016 choosing daily closing indices. Analysis of the correlation between the mentioned variables shows a negative coefficient value. As well, findings of the Granger causality test highlight a unidirectional causal relationship between NIFTY returns and exchange rates.

The former empirical studies validated that when inflationary pressure happen in a country due to some socioeconomic reasons, surely it will influence the prevailing stock market performance as the stock exchange market plays a fundamental job in the economic boom and encouraging capital accumulation and supporting economic prosperity [28], the rationale is that on every occasion the price of consumer products changes it will surely affect the stock market profitability in either direction (that is, negatively, positively, or may not the case due to some responsible factors). Few of the important studies are reported as follows.

The former study carried out by Mukherjee and Naka [29] examined the connection of stock prices in the Tokyo stock market with a group of macroeconomic variables. Their empirical verdicts of the ECM report a positive relation of the stock price with exchange rate, money supply and industrial production. Over the period starting from January 2000 to March 2010, Limpanithiwat and Rungsombudpornkul [30] have investigated the long-run association between stock prices and inflation in Thailand while introducing the impacts of Tsunami and global economic recession on the underlying relationship. The results of the VAR (Vector Autoregression) model display that volatility of stock prices is irrelevant to inflation. In addition, to capture the effects of inflation on the equity value, a number of direct interviews have also been conducted to assemble opinion of investors who investing in the stock market of Thailand. The results of interviewees also support the stated conclusion.

While using the ARDL bounds test, Ibrahim and Agbaje [31] have examined the long-run dynamic linkages between stock market returns and inflation in Nigeria using the monthly time series data from 1997 to 2010. The findings of the ARDL approach suggest that there exists a long-run co-integrating the relationship between stock returns and inflation. The results of the ECM show that the pace of convergence to equilibrium position is moderate which means that there is evidence of the short-run interactions between the two macro variables.

Using the quarterly data covering the January 1996 to December 2011 periods, Saleem et al. [32] had examined the long-run co-integrating relationship between the KSE-100 index and inflation through the use of Johansen techniques for Pakistan's economy. The evidence from Johansen procedure to cointegration yields an inverse linkage between the selected market index return and inflation due to the reason that Pakistan is not a developed country. When the inflation rate becomes high, it badly affects the economic performance, which in turn affects the stock market profitability and the responsible reasons for this backwardness are the prevailing economic conditions, huge budget deficit and the remaining other important economic factors. The empirical outcome of the Granger causality test indicates that there is no such evidence of a causal relationship between the said variables in any direction.

Solnik [33] investigated the economic impact of macroeconomic factors such as interest rate, exchange rate and inflation on stock prices for nine western economies, including France, UK, Switzerland, Canada, US, Belgium, Netherlands, Germany and Japan by using monthly dataset. After empirical investigation, he concludes depreciation to have a positive but insignificant effect on the United States equity market as compared to change in change in inflationary prospect and interest rates. In the same way, Hasan and Javed [34] discovered the long-run relationship of the PSX with a set of macroeconomic variables such as exchange rate, T-bill rate, money supply and inflation rate. The analysis of cointegration, Granger causality and impulse response shows that there exists an inverse relationship of the stock market with the interest rate and the exchange rate. Besides, Ahmad et al. [4] examined the impact of interest rate and exchange rate on the KSE-100 index of Pakistan uses the time series data covering the period 1998-2009 while applying the multiple regression models. The outcomes of the model concluded that there exists a significant relationship of the interest rate and exchange rate with the selected market index. The results also suggest a negative and significant relationship among the included variables.

Geetha et al. [35] have reinvestigated the interconnection between the equity market and macroeconomic indicators like expected plus unexpected inflation rate, interest rate, exchange rate and GDP for three selected countries, which are China, Malaysia and U.S. The results of the Johansen procedure confirmed about the long-run relationships among variables under examination for the whole countries. While the findings of the ECM report the absence of the short-run equilibrium relationship between market index and the rest of the variables for Malaysia and United States. Though, China's ECM verdicts reveal that there is a short-term link exists between equity market in China and anticipated inflation. And finally, Mukit [5] evaluated the macroeconomic effects of the interest rates and the exchange rates on stock market return by using monthly data for Bangladesh's economy, covering the 1997-2010 periods. By applying the cointegration technique, it was observed that a $1 \%$ rise in interest rate and exchange rate contributes $1.71 \%$ and $1.04 \%$ decline in stock market index, correspondingly. The estimated ECT coefficient value shows that $7.8 \%$ variation of stock returns is corrected in the short term. And lastly, the result of the Granger causality affirms the existence of a unidirectional causal relationship which is from the market index to exchange rate plus from interest rates to a stock market index.

\section{Data Description}

The macroeconomic variables included in this study consists of annual time series observations on stock 
market performance, interest rate, exchange rate and inflation rate for Pakistan covering the periods starting from 1991 to 2017. The Karachi Stock Exchange Index or the KSE-100 Index $(1991=1,000)$ has been used as a proxy for measuring the stock market performance variable which captures the daily price movements of equities in the stock exchange market in Pakistan. This index was launched in November 1, 1991 having a base value of 1, 000 points. Data on the KSE-100 index is taken from the Karachi Stock Exchange Indices (KHI Stocks) published by the Pakistan Stock Exchange Limited [36] and the remaining series of data have been updated from the website (www.opendoors.pk). The interest rate variable has been proxy by the discount rate or the bank rate, commonly known as the SBP's Reverse Repo (Ceiling) rate ${ }^{5}$. The change in interest rate has been calculated by taking log difference to bank rate, and can be written as:

$$
\text { Change in Interest rate }=\ln \left(\frac{I R_{t}}{I R_{t-1}}\right)
$$

Data on the interest rate variable has been collected from the State Bank of Pakistan until 2016 and the rest series have been updated from the Monetary Policy Statements and Pakistan Economic Survey 2016-17. As well, the variable exchange rate or foreign exchange rate is the price or purchasing power of the home currency in term of foreign currency. More explicitly, the foreign exchange rate is stated in terms of Pakistani rupee (PKR) against the United States dollar (USD), and can be calculated as:

$$
\begin{aligned}
& \text { Change in foreign exchange rate }(\triangle F E R) \\
& =\ln \left(\frac{F E R_{t}}{F E R_{t-1}}\right)
\end{aligned}
$$

Data on the average foreign exchange rate variable has been taken from the Statistics and Data Warehouse Department, State Bank of Pakistan until 2012 and the remaining sample observations on the same variable have been taken from the Domestic Markets and Monetary Management Department plus the Statistics and Data Warehouse Department, State Bank of Pakistan (2016) [37]. Also the last sample observation for the year 2017 on the exchange rate variable has been updated from the External Relations Department, State Bank of Pakistan (2017) [37]. The inflation rate variable has been proxy by the Consumer Price Index (CPI) which is the best statistic to measure the cost of living when compared with other measures, for example, the Wholesale Price Index (WPI), the Sensitive Price Indicator (SPI), the GDP deflator, and so forth. Note that the base year for measuring the inflation rate in Pakistan for the fiscal year 2000 and onward is $1999-00=100$ (PBS). As we deal with the annual data, therefore; the inflation rate (Y-O-Y) measures the annual percentage change in the CPI series. More to the point, July 2007 inflation rate (CPI value) will be the percentage change in CPI from July 2006. Yearly events have a tendency to be volatile in nature because they are largely affected by some major events, such as, stock market crash, natural calamities, disasters, earth quacks, years with many workers on vacation, etc. To calculate the year-wise change, the following formula has been suggested by the researchers.

$$
\text { Percentage Growth }=\frac{\text { YearA }- \text { YearB }}{\text { YearA }} * 100
$$

or

$$
\text { Inflation Rate }=\ln \left(\frac{C P I_{t}}{C P I_{t-1}}\right)
$$

Data on the inflation rate variable has been taken from the Pakistan Bureau of Statistics (PBS) and the remaining observations have been updated from different Pakistan Economic Surveys, published by the Ministry of Finance, Pakistan.

A few transformations have been made in the original data to stay away from spurious and ambiguous empirical results in the study and finale to present an effective set of policy suggestions. For instance, those variables that were originally available in the percentage form have been converted to the decimal notation. In the same way, all included variables in the study are changed to the natural logarithmic form to suit the operation of variance as one of the box-cox transformation. One of the advantages of the natural log transformation is that we get a smaller value of the coefficients after estimating them and hence, we can easily interpret the estimates for results.

Figure 1 plot all the variables over the selected time span, depicting more or less upward trend for exchange rate and stock market index, whereas; the more or less downward trend have been found for inflation rate and interest rate. This figure offers a glance at the historical background of the Pakistan economy. From the figure of inflationary trend (a), we can observe that inflation fluctuates considerably over time. The CPI value edged up to some extent in fiscal year 2001 after noticing a three decade low preceding year. The inflation rate stood at $4.67 \%$ in terms of the CPI in January FY01, while, based on the average rate of inflation, this rate rose to $4.4 \%$ in fiscal year 2001 from $3.6 \%$ in the prior year. The responsible reasons behind the observed inflation during FY01 were the oil price shocks ${ }^{6}$ in the international market, the Pakistan's currency depreciation against the US $\$^{7}$, impermanent shortage of pulses and gram, rise in issue prices of wheat ${ }^{8}$, hike in prices of specific fruits and vegetables, etcetera. Recently, the inflation rate has been recorded about 3 or $4 \%$ per year on average basis, signifying that prices have been somewhat stable from previous decades. A variety of responsible factors for such a big achievement includes the low oil and product prices, smooth supply of stuff, stable currency, and monitoring of prices at both national and provincial levels [13].

\footnotetext{
${ }^{5}$ This rate is formally known as the SBP 3-day repo rate which was renamed since Aug 17, 2009. This is the rate at which domestic banks borrow from SBP on an overnight basis. Also, at this rate the banks deposit their end-of-day excess cash with SBP on an overnight basis. It remained as SBP Policy rate till May 24, 2015.
}

\footnotetext{
${ }^{6}$ The price of POL increased

${ }^{7}$ The Pakistan's rupee was depreciated by $18.6 \%$ in terms of the USD

${ }^{8}$ By provincial governments
} 
(a) InCPI

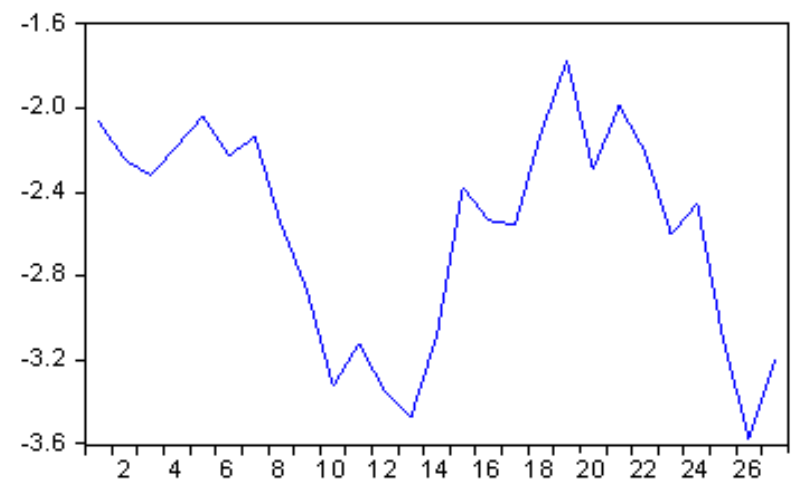

(c) $\ln \mathrm{R}$

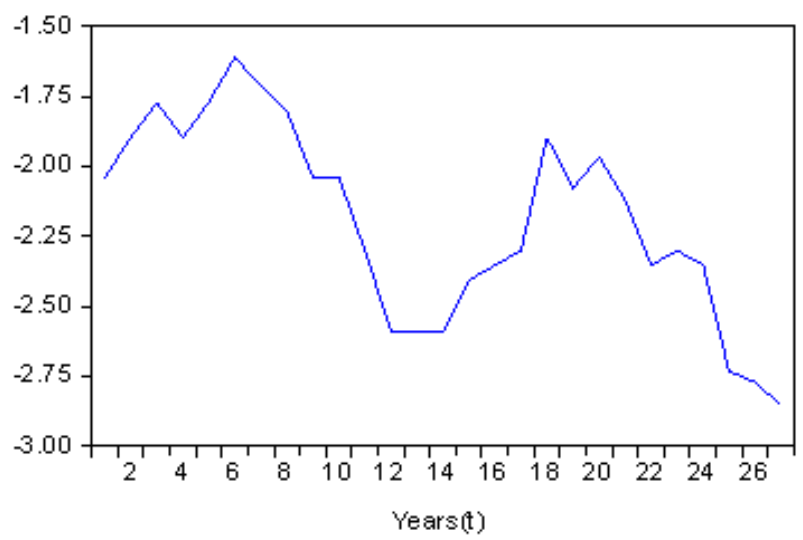

(b) $\ln \mathrm{EX}$

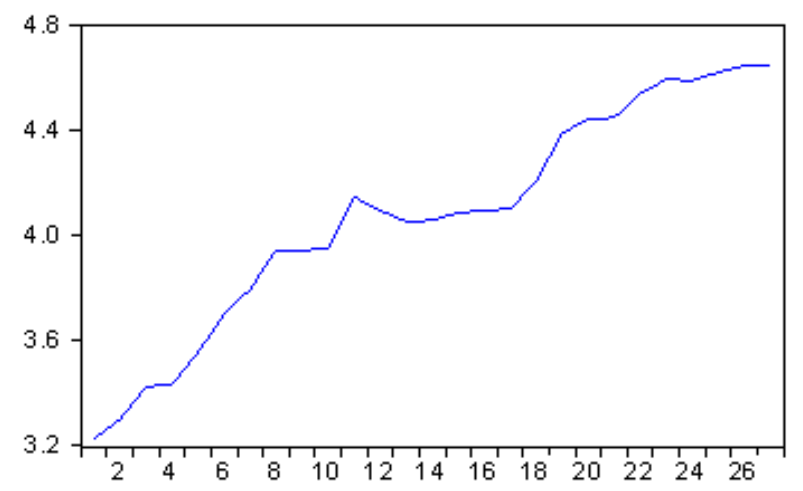

(d) InMI

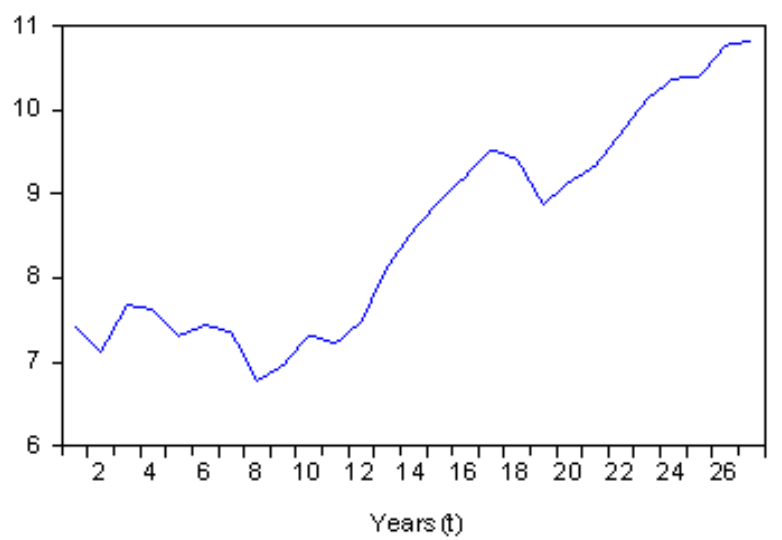

Figure 1. Plot of macroeconomic variables over the 1991-2017 sample periods (Source: Results extracted from the EViews 9)

From the rising exchange rate scatter plot (b), one can clearly perceive the idea that the Pakistan's currency has been quickly depreciated against the USD over the last two decades ${ }^{9}$. There are different reasons of currency depreciation in Pakistan which includes economic, political and corruption. The responsible interconnected economic reasons include the fiscal deficit, price shocks, faulty financial system, speculative pressure, expansionary fiscal plus monetary policy, real exchange rate, capital flight, low foreign direct investment, and so on. Despite the mentioned facts, the Pakistan rupee has remained stable at the rate Rs. $104 / \$$ in the open market roughly for the last two years due to the SBP's prudent management and effective monetary policy.

The figure (c) of interest rate variable illustrates the percentage change in the bank rate for each year since 1991 where the ups and downs can be clearly seen. It shows that initially this policy rate was set high at $13 \%$ in October FY91, where further increased at the rate has seen from the SBP's side and this rate reached to $14 \%$ in January FY92. Furthermore, the central bank also increased the bank rate from $9 \%$ to $9.5 \%$ (Economic Survey, 2005-06), and such increase in rate has remained high during the end of FY12 ${ }^{10}$. The increase in policy rates was in accord with the foreign rising trends as well as such steps was also taken to shorten the advancing ability of the banks to the private segment. This policy

${ }^{9}$ Pakistan's rupee against the USD depreciated by about $17 \%$ both in the open market and inter-bank during the fiscal year 2000-01 (Economic Survey, 2000-01).

${ }^{10}$ It was $12 \%$ in July $27,2012$. designed to curtail domestic aggregate demand from the private sector that was one of the foremost driving forces for fuelling inflation. The plot of exchange rate shows that the policy rate is continuously falling from its peak over the last few years. To ensure the economic stability on the national level, the central bank kept the bank rate at $5.75 \%$ in FY17 and continued the same in the successive periods. ${ }^{11}$

The scatter plot (d) of the stock market performance which is captured by the KSE-100 index signifies the upward trend over the sampling period. During the start of FY01-02, the central bank stimulated toward a proactive monetary policy management system. The central bank attained a degree of market calm and analysis for the future, making a $1 \%$ decrease in the policy rate in July and August, 2001. The stock markets have continued floating during the FY02-03. The KSE-100 index has observed an exceptional growth during the FY02, increasing from 1770.1 points in June-FY02 to 2902.4 points in Apr-FY03. Afterwards, the index reached to its magic high score of 3003.4 points during the May FY03, yielding an increase of $69.7 \%$ during the time under review. This target was touched due to the friendly macroeconomic policies of government, improvement in economic fundamentals, and assurance of local as well as foreign investors on the KSE market. ${ }^{12}$ During the FY17, the index reached at its

\footnotetext{
${ }^{11}$ It is the lowest policy rate by SBP since early 1970 s.

${ }^{12}$ Other main factors include the declining returns on alternative investments, huge foreign exchange reserves, expectations of early privatization (state enterprises and banks), liberalization and deregulation, strong presence of energy stocks in the market, reforms by the SECP, etc.
} 
highest position of 50,935.91 points on 08 May, 2017 while its lowest level was $37,966.76$ points on 04 July, 2016 [13].

\section{Theoretical and Modeling Framework}

\subsection{Analytical Framework}

This research study proposes the framework in Geetha et al. [35], Mukit [5,22], Mbulawa [70], Ihsan et al. [9], Rabia and Khakan [38], Sichoongwe [39], and Kennedy and Nourizad [40] in econometrically estimating the relationship between stock market performance with an interest rate, exchange rate and inflation rate in a time series setup. These listed studies estimated the structural model to empirically investigate the interactions between stock market performance with an interest rate and exchange rate in the log transformed form. Additionally, we introduce the Consumer Price Index (CPI) as variable to proxy for inflation rate, which turns the prices of a fixed basket of commodities ${ }^{13}$ into a single value (index) reflecting the general level of prices in the economy plus measures the rise in the cost of living of citizens. This variable has got importance in the analysis especially after the global financial crises of 2007-08.

The background theory suggests that the stock market performance in Pakistan depends on interest rate, exchange rate and inflation rate, which can be written in the functional form in equation 1 as follows:

stock market performance $=$

$f$ (interest rate, exchange rate, inflation rate)

The same functional relationship of the model can be symbolically written as given in equation 2 :

$$
M I=f(I R, E X, C P I)
$$

We have converted the basic linear illustration of the model into the log-linear form ${ }^{14}$ due to the reason that it gives more efficient results and avoid non-sense regression as compare to the original functional specification [41] and Ehrlich $[42,43]$. Also, such sort of conversion in variables provides elasticity estimates in the form of coefficients which a researcher can directly and easily interpret for policy purposes. For example, the log form offers direct estimation of the company return elasticity which permits the PSX profits to respond proportionately to changes in exchange rates. Accordingly, the structural model in the $\log$-linear form of all variables under examination can be stated in equation 3 as follows:

$$
\begin{aligned}
\ln M I_{t}= & \beta_{1}+\beta_{I R} \ln I R_{t}+\beta_{E X} \ln E X_{t} \\
& +\beta_{C P I} \ln C P I_{t}+\varepsilon_{t}
\end{aligned}
$$

Where,

$\ln M I_{t}=\log$ of the stock market index or log of the KSE-100 index at time $t$

\footnotetext{
${ }^{13}$ The Laspeyres index is the price index, which measures the general price level for a fixed basket of commodities (goods and services).

${ }^{14}$ It is the model type where both the explained and explanatory variables appear in logarithmic form.
}

$\ln I R_{t}=\log$ of the interest rate or log of the SBP's Reserve Repo rate at time $t$

$\ln E X_{t}=\log$ of the exchange rate or the Pakistani rupee per US\$ at time $t$

$\ln C P I_{t}=\log$ of the inflation rate or log of the Consumer Price Index at time $t$

$\beta_{1}=$ constant term or intercept

$\beta_{i}=$ slope coefficients of the independent variables or elasticities

$\varepsilon_{t}=$ error term or residual or stochastic disturbance term $t=$ time unit, or $t_{1}=1991$ and $t_{27}=2017$

The conventional finance theory implies that if the interest rate falls, the investments with fixed income turn out to be less competitive due to their lower returns, so consequently, stocks turn out to be more attractive. In opposition, when interest rate increases, the investments with fixed income turn out to be more competitive due to their higher returns, and as a consequence, stocks become less striking. This logic, meaning that there is an opposite relationship of the stock valuations with the interest rates. Therefore, we expect $\beta_{I R}<0$.

Furthermore, there exists a clear dichotomy in the finance literature on the relationship of stock prices/returns with exchange rates. Some of the research studies recommend that there exist a positive correspondence between the stock prices and the foreign exchange rate, for instance, Aggarwal [44], Smith [45], Sabri [46], Ahmad et al. [4], etc. In contrast, other empirical works have concluded a negative link between stock prices and foreign exchange rates, and such studies include Soenen and Hanniger [47], Granger et al. [48], Yusuf and Rahman [49], and so on. However, works like Ma and Kao [50], Beirne et al. [51], etc. have established mixed results on the relationship between stock returns and exchange rates. Hence, we expect $\beta_{E X}>0$ or $\beta_{E X}<0$.

At last, the effect of price hiking on stock returns is totally based on the level (severity) of inflation. Earlier research attempts have suggested that inflation and stock exchange markets are strongly correlated with the inflation rate affecting the stock exchange market risk plus volatility. These financial markets encourage savings as well as investments by ensuring an opportunity for portfolio diversification equally to clients plus corporate investors. The severity of the general prices on the financial market performance significantly persuades the prices of financial assets which are basically determined by the net profits of a company and are therefore straightforwardly proportional to the behavior of a company. So, an extremely inflationary situation, therefore negatively influences the stock prices and ultimate stock returns. And so, we expect $\beta_{C P I}<0$.

\subsection{Estimation Strategy}

The technique for empirical investigation in this paper is the ARDL (Autoregressive Distributed Lag) or bound cointegration approach originally developed by Pesaran and Pesaran [52], Pesaran and Shin [53] and Pesaran et al. $[54,55]$ to explore the long run relations between stock 
market performance (market index), interest rate, exchange rate and inflation rate over the sampling period. This cointegration model can be used for analysis, exclusive of finding the order of integration. According to Haug [56], this technique to cointegration is best in providing the best outcomes for small datasets (and the same is the case here), in contrast to other methodologies of cointegration ${ }^{15}$ found in the literature of Applied Econometrics. Also, one feature of the ARDL approach is that the unrestricted technique of the ECM has enough flexibility to include lags that captures the data generating process in a general-to-specific structure of the arrangement [57]. As each of the variables included in the model appear as a sole equation, the problem of endogeneity is less crucial in the bound testing approach as it is free of residual correlation [58]. Additionally, one of the features of the ARDL technique lies in its pure identification of the cointegration vectors among the multiple cointegrating vectors. As well, this approach has the ability of differentiation between explained and independent variables when we are dealing with the single long run relationship. Specifically, this methodology supposes that only a single reduced-form equation relationship exists between the explained variable and the exogenous variables [55].

The generic form of an ARDL regression model is given in equation 4 as under:

$$
\begin{aligned}
& Y_{t}=\beta_{0}+\beta_{1} Y_{t-1}+\ldots \ldots+\beta_{k} Y_{t-p}+\alpha_{0} X_{t}+ \\
& \alpha_{1} X_{t-1}+\alpha_{2} X_{t-2}+\ldots \ldots+\alpha_{q} X_{t-q}+\varepsilon_{t}
\end{aligned}
$$

We can observe from the appearance of the general ARDL approach set in equation 4 above, that such specifications are illustrated by having lags of the explained variable, plus lags (and possibly the current value) of the independent variables. The conventional ECM or the unrestricted ARDL approach would be of the type:

$$
\begin{aligned}
\Delta Y_{t} & =\beta_{0}+\sum_{i=1}^{p} \beta_{i} \Delta Y_{t-i}+\sum_{j=0}^{q 1} \gamma_{j} \Delta X_{1 t-j} \\
& +\sum_{k=0}^{q 2} \delta_{k} \Delta X_{2 t-k}+\varphi Z_{t-1}+e_{t}
\end{aligned}
$$

In equation 5 above, ' $Z$ ' is the error-correction term in the model which is the OLS disturbance term series from the long run cointegration regression. That is to say,

$$
Y_{t}=\alpha_{0}+\alpha_{1} X_{1 t}+\alpha_{2} X_{2 t}+V_{t}
$$

The unrestricted ARDL model is given in equation (7) as follows:

$$
\begin{aligned}
\Delta \ln M I_{t}= & \alpha_{1}+\alpha_{I R} \ln I R_{t-1}+\alpha_{E X} \ln E X_{t-1}+ \\
& \alpha_{C P I} \ln C P I_{t-1}+\sum_{i=1}^{p} \alpha_{i} \Delta \ln M I_{t-i}+ \\
& \sum_{j=0}^{q} \alpha_{j} \Delta \operatorname{lnIR_{t-j}}+\sum_{k=0}^{n} \alpha_{k} \Delta \ln E X_{t-k} \\
& +\sum_{l=0}^{n} \alpha_{l} \Delta \ln C P I_{t-l}+\mu_{t}
\end{aligned}
$$

\footnotetext{
15 The other pioneering techniques include the Engle-Granger methodology (1987), Johansen and Juselius (1990) methodology, Phillips and Hansen (1990) and Phillips and Loretan (1991) works.
}

In applied econometrics, cointegration is an influential way of perceiving the existence of the steady-state equilibrium between variables. It has become a principal condition of every economic model analyzing the non-stationary data. If the variables under consideration don't cointegrate with each other, in that case we have the spurious regression problems and the regression results therefore become almost insignificant. Alternatively, if the examined variables do cointegrate with each other, in that case we have a cointegration property [58]. In order to find out the cointegration relations among the examined variables under study through the ARDL methodology, the hypothesis can be tested with the tabulated critical values given by Pesaran et al. [55]. As in typical cointegration testing, we set the null hypothesis for the nonexistence of a long term equilibrium association between the examined data, in opposition to the substitute assumption that there exists such kind of relationship between the variables. The null hypothesis of no cointegration among the variables in the stated model can be written as: $H_{0}: \alpha_{I R}=\alpha_{E X}=\alpha_{C P I}=0$. The alternative hypothesis of cointegration among the variables under study can be written as: $H_{1}: \alpha_{I R} \neq \alpha_{E X} \neq \alpha_{C P I} \neq 0$.

The next step in such analysis is to conduct an F-test, where we compare the F-statistic calculated values with the lower and upper critical bound values as given by Pesaran and Pesaran [52] or Pesaran et al. [55] in their respective studies. However, there is a convenient complexity that has to be resolved when we perform the F-test. The distribution of this statistic is entirely non-standard even if we have a substantially large sample data. This is rather similar to the condition to the Wald-test when we check for Granger non-causality when we have non-stationary series. Therefore, the issue is set on by using the Toda-Yamamoto method (1995), to make certain that the Wald-test statistic is asymptotically chi-square. As suitable critical values for the F-statistic are not exists for the mixed results of variables (i-e. $\mathrm{I}_{0}$ and $\mathrm{I}_{1}$ ). Though, Pesaran et al. [55] provide bounds on the critical values for the asymptotic distribution of the F-test. For different cases, they presented lower bounds and upper bounds on the critical values. In each situation, the lower bound stand on the postulation that all of the variables are stationary at levels $\left(\mathrm{I}_{0}\right)$, and the upper bound stand on the postulation that all of the variables having unit root $\left(\mathrm{I}_{1}\right)$. In reality, the fact may be someplace in between these two extreme cases. In case of the small time series sample, Turner [59] has collected critical bounds for the F-test that is appropriate for the short hand data. If the F-statistic value is more than the upper critical bound, we would establish that there is a cointegration among variables. If the F-statistic computed value falls below the lower critical bound, we would establish that there is no cointegration among the variables, meaning that the variables are stationary at level, i-e. I (0). Conclusively, if the F-statistic calculated value falls between the two polar bound, the result or decision is inconclusive. In order to explore the long-run relations among variables in such cases, we depend on the significance of the lagged error correction term (ECT) for cointegration. After confirming the long run relations among included variables, the short term behavior of 
examined variables is explored in equation 8 by the vector ECM (VECM) model:

$$
\begin{aligned}
\Delta l n M I_{t}= & \delta_{1}+\sum_{j=0}^{p} \delta_{2} \Delta \ln I R+\sum_{k=0}^{q} \delta_{3} \Delta \ln E X_{t-k} \\
& +\sum_{l=0}^{o} \delta_{4} \Delta \ln C P I_{t-l}+\omega E C M_{t-1}+\varepsilon_{t}
\end{aligned}
$$

The presence of an ECT suggests the changes in explained variable $\left(\Delta I n M I_{t}\right)$ which is a function of the disequilibrium levels in the cointegration relations plus the changes in other independent variables under consideration. This result shows the variations in explained variable from a short period of time to long run equilibrium path [60]. It demonstrates the magnitude to which any variability in the preceding time is being adjusted in dependent variable. Its positive coefficient point out a divergence whereas, a negative value of its coefficient signifies convergence. If its estimated value equal to one, then a hundred percent of the adjustment occurs within the period. If its estimated value equal to 0.5 , then fifty percent of the adjustment occurs each period. Lastly, if its value is zero, meaning that there is no adjustment occurs, also to argue that there is a long-run relationship doesn't make any logic any longer.

\section{Empirical Results and Discussion}

In the views of Pesaran and Shin [53] and Pesaran et al. [55], the ARDL approach can be implemented in finding the long run relations among variables having the mixed order of integration. This methodology can be used for the purpose to integrate I (0) and I (1) series in the same estimation process. If variables included in the model are all stationary at level I (0), then the Ordinary Least Squares (OLS) technique is best for estimation. And, if all data series are non-stationary at level I (1), then the Johansen approach to cointegration is advisable due to its simple estimation practice. Therefore, we cannot use the OLS technique on the series if one of them or all of them is non-stationary due to the reason that these series will not act as constants anymore and some of them are time variant. The OLS technique will by mistake give high t-statistic values and significant outcomes, but in a real situation, it would be inflated due to the common time component ${ }^{16}$.

ARDL approach doesn't need pretest for unit roots. However, it may be desirable to test for unit roots in variables, although not as a required condition. Subsequently, this approach to cointegration is superior to others when involving with series that are integrated of a different order, I (0), I (1) or both types of combination. Though, this approach will collapse in the incidence of the integrated stochastic trend of I (2) ${ }^{17}$. Ouattara [61] expressed that if any series in the dataset is integrated at I (2), in that case the F-test calculation for cointegration

\footnotetext{
${ }^{16}$ In econometric theory, such results are known as meaningless regression results where $\mathrm{R}^{2}$ becomes higher than the D-W statistic of the model and such results are undesirable for devising an effective economic policy.

${ }^{17}$ The methodology to cointegration will remain invalidate for such kind of data.
}

becomes indecisive. The reason is that the critical bounds given by Pesaran et al. [55] are completely relying on the hypothesis that such a series of variables should be stationary at levels or stationary at their first difference. That is the reason; we check unit root tests to certify that no series is integrated at their second difference I (2).

\subsection{Statistical Analysis}

There are some preliminary steps which are needed to be carried out before going to an ARDL procedure to cointegration. The whole dataset consists of twenty seven years of annual observations from 1991 to 2017. Descriptive statistics provide simple summaries about the sample and about the observations that have been made. The summary of descriptive statistics of the whole dataset is presented in Table 2 .

Table 2. Statistical Analysis Summary

\begin{tabular}{|l|c|c|c|c|}
\hline Statistic Name & $\operatorname{lnMI}$ & $\operatorname{lnIR}$ & $\operatorname{lnEX}$ & $\operatorname{lnCPI}$ \\
\hline Mean & 8.559699 & -2.191032 & 4.077736 & -2.583671 \\
\hline Median & 8.571526 & -2.120264 & 4.096419 & -2.453408 \\
\hline Maximum & 10.83154 & -1.609438 & 4.652054 & -1.771957 \\
\hline Minimum & 6.779490 & -2.855970 & 3.226411 & -3.575551 \\
\hline Standard Deviation & 1.294407 & 0.349715 & 0.430395 & 0.516289 \\
\hline Skewness & 0.299251 & -0.236382 & -0.391736 & -0.488427 \\
\hline Kurtosis & 1.710099 & 2.014896 & 2.193306 & 1.969984 \\
\hline Jarque-Bera & 2.274806 & 1.343176 & 1.422655 & 2.267076 \\
\hline Probability & 0.320651 & 0.510897 & 0.490992 & 0.321892 \\
\hline Observations (n) & 27 & 27 & 27 & 27 \\
\hline
\end{tabular}

Source: Output from EViews 9

The Table 2 report's summary of the descriptive statistics, which illustrates that the average of market index points is 8.56 with a standard deviation of 1.29 , the average of interest rate is -2.19 with a standard deviation of 0.35 , the average of Pakistani rupee against the US\$ is 4.08 with a standard deviation of 0.43 and the average of inflation rate is -2.58 with a standard deviation of 0.52 . All given variables of the model are negatively skewed except the stock market index which is positively skewed. Furthermore, kurtosis statistic of the dataset showing that the EX and IR variables are leptokurtic (high peak/long tailed) and CPI and MI variables are platykurtic (lower peak/short tailed). As a final point, the Jarque-Bera statistic confirms that the disturbances are normally distributed because the corresponding probability value for each variable is more than $5 \%$, hence we accept the null hypothesis meaning that the residuals are normally distributed $^{18}$. In a compact form, we can write this finding as: $u_{i} \sim N\left(0, \sigma^{2}\right)$ or $u_{i} \sim N I D\left(0, \sigma^{2}\right)$.

\subsection{Correlation Analysis}

In order to check multicollinearity among variables under examination, a correlation analysis has been suggested in the literature. Originally multicollinearity refers a situation in which two or more than two independent variables in a multiple regression model are highly linearly

\footnotetext{
${ }^{18} \mathrm{H}_{0}$ : Residuals are normally distributed, and $\mathrm{H}_{1}$ :Residuals are not normally distributed
} 
related. Based on the rule of thumb, if the intercorrelation between two independent variables is greater than 0.8 , then we have strong or significant multicollinearity in the data. Such kind of analysis measures the degree to which the two regressors move together. The sign of the Pearson correlation coefficient (PCC) test ${ }^{19}$ decides about the nature of the relationship, whereas, its coefficients calculate strength of the relationship between the pairwise correlations. Outcomes of the Pearson correlation test are reported in following Table 3 .

Table 3. Results of Intercorrelations

\begin{tabular}{|c|c|c|c|c|}
\hline Symbol & $\operatorname{lnMI}$ & $\operatorname{lnIR}$ & $\operatorname{lnEX}$ & $\operatorname{lnCPI}$ \\
\hline $\operatorname{lnMI}$ & 1.0000 & -0.6487 & 0.8151 & -0.1461 \\
\hline $\operatorname{lnIR}$ & -0.6487 & 1.0000 & -0.6473 & 0.7020 \\
\hline $\operatorname{lnEX}$ & 0.8151 & -0.6473 & 1.0000 & -0.3277 \\
\hline $\operatorname{lnCPI}$ & -0.1461 & 0.7020 & -0.3277 & 1.0000 \\
\hline $\begin{array}{l}\text { Note: All the tabulated values have been rounded-off to four decimal } \\
\text { places. }\end{array}$
\end{tabular}

Source: Outcome from EViews 9

The Table 3 illustrates what is call correlation matrix. Analysis of the correlation matrix clearly depicts that both interest rate and inflation rate are negatively correlated with the stock market index and the exchange rate is positively correlated with the same market index. Also, some series of variables are negatively correlated and others are positively correlated with each other. The interest rate variable is negatively correlated with all variables in the model, except for the inflation rate. Furthermore, the EX and CPI are negatively correlated among themselves, whereas, the correlations between exchange rate and interest rate and inflation rate and interest rate were found negative and positive, respectively. And finally, intercorrelations also confirm that inflation rate is positively and highly correlated with interest rate ${ }^{20}$. From the whole analysis of intercorrelations, we can conclude that our data has no issue of exact or perfect multicollinearity as none of the PCC between explanatory variables is more than 0.8 .

\subsection{The Unit Root Test}

In order to escape from the nonsensical and meaningless results, the variables included in the economic model must be stationary since it is not possible to obtain reliable estimates and making forecasting with a nonstationary dataset. That's why; checking the stationary properties of a series is a natural begin of an empirical investigation in almost every time series study. There are many tests in time series Econometrics for such purpose, but the widely used and the most famous amongst them over the last numerous years are the unit

${ }^{19}$ The sample Pearson correlation coefficient can be calculated using the following formula:

$$
r=r_{x y}=\frac{n \sum x_{i} y_{i}-\sum x_{i} \sum y_{i}}{\sqrt{n \sum x_{i}^{2}-\left(\sum x_{i}\right)^{2} \sqrt{n \sum y_{i}^{2}-\left(\sum y_{i}\right)^{2}}}}
$$

${ }^{20}$ This argument is based on only for the intercorrelations among independent variables. root tests [62]. For such a purpose, there are many tests in the literature such as the Dickey-Fuller (DF) test, Phillips-Perron (PP) unit root test, Ng-Perron test, Augmented Dickey-Fuller (ADF) test, and so forth. The most frequently demonstrated test amongst all for checking stationarity on a set of data is the ADF test because of its quality of relaxing the postulation of autocorrelation among residuals. If a series under analysis is found stationary at level form, we say that it is integrated of order zero, denoted by I (0). Conversely, if a series of data is found non-stationary at level form, but stationary at their first difference, we can call it integrated of order one and is denoted by I (1). To find the long run relations among variables, the order of integration is significant in deciding the appropriate procedure to cointegration. The ADF test detailed outcomes are given in Table 4.

In Table 4, column first represents variables names. Columns second and third give details of first and second difference estimates of coefficients together with standard error and probability value. The order of stationary for each variable is given in the last column of the table. Additionally, the stock market index variable has got unit root at the level and its plot reveals the same fact. Specifically, based on the intercept form, $t-$ statistic $=\frac{\hat{\beta}}{s_{\hat{\beta}}}=\frac{0.019514}{0.052154}=0.37<1.9$. Also, we then checked the unit root at level based on the trend and intercept criteria and got the same result from the p-value at $5 \%$ significance level. Now, at first difference, at intercept form, the estimated coefficient and standard error are, (-0.871829) and (0.199175), correspondingly, giving the ADF test-statistic value of (-4.38). At the present, t-statistic confirms significant results (as $|4.38|>1.9$ ), which means that at first difference, we have no unit root in the dependent variable. The similar guideline is followed for the rest of all explanatory variables. At the final note, results of the ADF test indicate that all of the explanatory variables are stationary at their level because their plots have the mean reverting behavior.

\subsection{Optimal Lags Selection}

The ARDL bounds test methodology as established by Pesaran et al. [55] involves an appropriate lags length in dataset to eliminate any serial correlation. Empirical results of long run relations among variables are highly responsive to lag length specified in the econometric model [63]. The optimal order of lag length has been chosen by determining the $1 \mathrm{st}$ difference of the conditional ECM of time series ARDL. There are many criteria for selecting the order of adequate lag length, but the most important criteria among them are the Akaike Information Criterion (AIC) and Schwarz Information criterion (SC). In this paper, the optimal lag is selected based on the ground of minimum value of AIC. According to the AIC criterion, lower the value of AIC, better the model. There is confirmation that the F-statistic calculated value of the ARDL model is very much sensitive to the choice of order of lag in the economic model. In the presence of adequate lag order, the researchers can get 
unbiased, efficient and reliable empirical verdicts. Detailed outcomes are listed in the Table 5.

From the Table 5, we can see that there are many criteria to choose the number of lags that can be used in the system equation. According to the AIC criterion, 2 lags should be used in the dataset before for going into the long run relationship among variables in the model.

Table 4. The ADF Test Results

\begin{tabular}{|c|c|c|c|c|c|c|c|c|}
\hline \multirow{2}{*}{\multicolumn{2}{|c|}{ Variables }} & \multicolumn{3}{|c|}{ Intercept } & \multicolumn{3}{|c|}{ Trend and Intercept } & \multirow{2}{*}{ Conclusion } \\
\hline & & Coefficient & S.E & Prob.* & Coefficient & S.E & Prob.* & \\
\hline \multirow{2}{*}{$\mathrm{MI}_{\mathrm{t}}$} & Level & 0.019514 & 0.052154 & 0.9777 & -0.472483 & 0.130747 & 0.0508 & \multirow{2}{*}{$\mathrm{I}(1)$} \\
\hline & $1^{\text {st }}$ Difference & -0.871829 & 0.199175 & $0.0022 * *$ & -0.913384 & 0.210081 & 0.0106 & \\
\hline \multirow{2}{*}{$\mathrm{IR}_{\mathrm{t}}$} & Level & -0.063451 & 0.108581 & 0.8575 & -1.076173 & 0.248413 & $0.0131 * *$ & \multirow{2}{*}{$\mathrm{I}(0)$} \\
\hline & $1^{\text {st }}$ Difference & -0.938961 & 0.204216 & 0.0013 & -0.966608 & 0.210866 & 0.0063 & \\
\hline \multirow{2}{*}{$\mathrm{EX}_{\mathrm{t}}$} & Level & -0.058675 & 0.30440 & 0.3152 & -1.038871 & 0.236218 & $0.0115^{* *}$ & \multirow{2}{*}{$\mathrm{I}(0)$} \\
\hline & $1^{\text {st }}$ Difference & -0.912187 & 0.209929 & 0.0023 & -0.984336 & 0.213481 & 0.0059 & \\
\hline \multirow{2}{*}{$\mathrm{CP}_{\mathrm{t}}$} & Level & -1.269603 & 0.293806 & $0.0034 * *$ & -0.659489 & 0.189874 & 0.0674 & \multirow{2}{*}{$\mathrm{I}(0)$} \\
\hline & $1^{\text {st }}$ Difference & -1.012695 & 0.214588 & 0.0010 & -1.018417 & 0.220503 & 0.0058 & \\
\hline \multicolumn{9}{|c|}{ *Mackinnon (1996) one-sided p-values } \\
\hline
\end{tabular}

Note: All hypotheses are tested at 5\% level of significance.

Source: Outcome from EViews 9

Table 5. Results of lag length selection

\begin{tabular}{|c|c|c|c|c|c|c|}
\hline \multicolumn{9}{|c|}{ VAR Lag Order Selection Criteria } \\
\hline Lag & LogL & LR & FPE & AIC & SC \\
\hline 0 & -43.03034 & --- & 0.000506 & 3.762427 & 3.957447 & $-2.192822 *$ \\
\hline 1 & 59.59903 & 164.2070 & $5.06 \mathrm{e}-07$ & -3.167922 & -2.897471 & -2.057553 \\
\hline 2 & 83.65918 & $30.79699 *$ & $2.97 \mathrm{e}-07 *$ & $-3.812735^{*}$ & $-3.325922 *$ \\
\hline
\end{tabular}

LR: sequential modified LR test statistic (each test at 5\% level)

FPE: Final Prediction error

AIC: Akaike Information criterion

SC: Schwarz Information criterion

HQ: Hannan-Quinn information criterion

Source: Outcome from EViews 9

\subsection{Testing for Cointegration}

A large number of procedures for testing cointegration among variables have been suggested in the econometrics literature. In order to check for the long-run relations among variables, we have calculated the test statistic of the F-test by the ARDL bounds test, applying the unrestricted OLS technique following equation 7. The following null hypothesis has been tested against the alternative hypothesis using the ARDL bounds test and its thorough results are given in Table 6.

$H_{0}$ : No long-run relationships exist among variables

$H_{1}$ : Long-run relationships exist among variables.

Table 6 indicates the calculated F-statistic and its critical values at $1 \%, 2.5 \%, 5 \%$ and $10 \%$ significance level in both polar extremes, i-e. at level 1(0) and at first difference 1 (1). The empirics show that the F-statistic computed value (which is 12.51) falls above the upper bound I (1) and is more than 4.35 of the F-test critical value at 5\% significance level given by Pesaran et al. [55], and therefore we can reject the null hypothesis. This finding concludes the presence of cointegration among examined variables, i-e. the stock market index is cointegrated with interest rate, exchange rate and inflation rate when the KSE-100 index appears as a dependent variable in the model.
Table 6. Results from ARDL bounds test

\begin{tabular}{|c|c|c|c|}
\hline \multicolumn{4}{|c|}{ ARDL Bounds Test to Cointegration } \\
\hline \multicolumn{4}{|c|}{ Estimated Equation: $\mathrm{MI}_{\mathrm{t}}=\mathrm{f}\left(\mathrm{IR}_{\mathrm{t}}, \mathrm{EX}_{\mathrm{t}}, \mathrm{CPI}_{\mathrm{t}}\right)$} \\
\hline \multicolumn{4}{|c|}{ Selected Optimal Lags/AIC Lags: 2} \\
\hline Test Statistic & Value & $\mathrm{k} * * *$ & \multirow{2}{*}{ Conclusion } \\
\hline F-statistic & $12.51466^{*}$ & 3 & \\
\hline \multicolumn{3}{|c|}{ Critical Value Bounds } & \multirow{6}{*}{ Cointegration $^{21}$} \\
\hline Significance & $\mathrm{I}(0)$ Bound & I(1) Bound & \\
\hline $10 \%$ & 2.72 & 3.77 & \\
\hline $5 \%$ & $3.23 * *$ & $4.35^{* *}$ & \\
\hline $2.5 \%$ & 3.69 & 4.89 & \\
\hline $1 \%$ & 4.29 & 5.61 & \\
\hline \multicolumn{4}{|c|}{$\begin{array}{l}\text { Note: I (0) show lower critical bound value and I (1) represent upper } \\
\text { critical bound value. } \\
* \text { specify significant at the } 5 \% \text { level } \\
* * * \mathrm{k} \text { is the number of independent variables for explained variable in } \\
\text { ARDL model }\end{array}$} \\
\hline
\end{tabular}

Note: **The above, I (0) and I (1) tabulated values (which are, 3.23 and 4.35 at 0.050 or $5 \%$ significance level) for an F-statistic is obtained from Table CI (iii) Case III: Unrestricted intercept and no trend introduced by Pesaran et al. (2001).

Source: Outcome from EViews 9

${ }^{21}$ It means that despite being in isolation nonstationary series, but its linear combination between or among time series variables can be stationary. 


\subsection{Long Run ARDL}

Cointegration of two or more than two time series variables implies that there exists an equilibrium or long-run relationship between them. Table 7 reports the empirical verdicts of long-run relations among regressors of the proposed ARDL model $(1,2,0,2)$ via SBC.

Table 7. Long-run ARDL Estimates

\begin{tabular}{|c|c|c|c|c|}
\hline \multicolumn{5}{|c|}{ Dependent Variable $=1 n$ MI } \\
\hline Selected Model: ARDL $(1,2,0,2)$ \\
\hline Variable/Regressor & Coefficient & $\begin{array}{c}\text { Standard } \\
\text { Error }\end{array}$ & t-statistic & Probability \\
\hline Constant $(\mathrm{C})$ & 1.213949 & 1.275963 & 0.951398 & 0.3556 \\
\hline $\operatorname{lnIR}_{\mathrm{t}}$ & -5.919177 & 0.763974 & $-7.747877 *$ & 0.000 \\
\hline $\operatorname{lnEX}_{\mathrm{t}}$ & 0.331953 & 0.421151 & 0.788204 & 0.4421 \\
\hline $\operatorname{lnCPI}_{\mathrm{t}}$ & 2.597753 & 0.401570 & $6.468998^{*}$ & 0.000 \\
\hline Note: *indicate significance level at the $1 \%^{\circ}$ \\
\hline
\end{tabular}

Source: Outcome from EViews 9

The finding shows that an increase in interest rate reduces in stock market index points. The effect of interest rate on the stock market performance of Pakistan is greatly significant at the $1 \%$ level of significance. The estimate (-5.9) of lnIR indicates that a $1 \%$ increase in bank rate leads to an about 6 percent $(5.9 \%)$ fall in stock market index points in the long-run. Similarly, the inflation rate is another highly significant time series to the stock market performance. At the $1 \%$ significance level, the effect of inflation rate on the stock market index points is positive. The coefficient of lnCPI, which is 2.6 after being rounded-off, shows that a $1 \%$ rise in inflation rate leads to an increase in market index points by $2.6 \%$ in the long-run. Finally, the coefficient on the exchange rate (lnEX) signifies a positive impact on $\operatorname{lnMI}$. That is, the coefficient of $\operatorname{lnEX}$ on $\operatorname{lnMI}$ is positive, comparatively smaller and statistically insignificant. It means that if the exchange rate depreciates by $1 \%$ results in a $0.33 \%$ rise in market index points ${ }^{22}$. The results in this study support the findings of Solnik [33] who conducted his study on the western market economies. Basically, the cointegrating equation can be written as:

$$
\begin{aligned}
& \text { Cointegrating Equation } \\
& \begin{aligned}
= & \ln K S E-(-5.9192 * \ln I R+0.3320 * \ln E X \\
& +2.5978 * \ln C P I+1.2139)
\end{aligned}
\end{aligned}
$$

\subsection{Short Run Dynamics}

The ECM proposed by Engle and Granger is a technique of analyzing the short term behavior of a variable with its long term behavior over the time. If the economic variables are found to be cointegrated with each other, the disturbances from the long-run regression can be applied to empirically estimate the error correction model and to examine the long-run plus short-run effects of the economic variables and to notice the adjustment coefficient. The numerical results of the error correction

\footnotetext{
${ }^{22} \mathrm{All}$ of the estimated coefficients values in the table are interpreted in the percent form because all the included variables in the ARDL model are in $\log$ from.
}

version of the proposed ARDL model by following equation 8 are given below in Table 8 .

Table 8. Short-run Model Estimates

\begin{tabular}{|c|c|c|c|c|}
\hline \multicolumn{5}{|c|}{ ECM Demonstration of the ARDL $(1,2,0,2)$ Model } \\
\hline Variable & Coefficient & $\begin{array}{c}\text { Standard } \\
\text { Error }\end{array}$ & t-statistic & Probability \\
\hline Constant $(\mathrm{C})$ & 0.355340 & 0.068209 & 4.769783 & 0.0001 \\
\hline$\Delta \operatorname{lnIR} \mathrm{t}_{\mathrm{t}}$ & -0.613661 & 0.313121 & -1.959500 & $0.0677 * *$ \\
\hline$\Delta \operatorname{lnEX}_{\mathrm{t}}$ & 0.154450 & 0.212571 & 0.726581 & 0.4780 \\
\hline$\Delta \operatorname{lnCPI}_{\mathrm{t}}$ & 0.083637 & 0.174987 & 0.477963 & 0.6391 \\
\hline $\mathrm{ECM}_{\mathrm{t}-1}$ & -0.465275 & 0.091125 & -5.105890 & $0.0001 *$ \\
\hline Note: $*$ and $* *$ & shows significance at $1 \%$ and $10 \%$ level, respectively \\
\hline
\end{tabular}

Source: Outcome from EViews 9.

From the Table 8, coefficients of economic variables with delta symbol $(\Delta)$ indicate the short-run elasticity estimates or short-run coefficients. The estimated results show that in the short-run $\mathrm{IR}_{\mathrm{t}}$ once more is the main significant economic variable responsible for the upward trend in the stock market performance. Evidence shows that a rise in interest rate in the short-run causes a decrease in market index points. For instance, a $1 \%$ increase in interest rate decreases stock market index points by $0.61 \%$ at 10 percent significance level. On the other side, the impact of exchange rate depreciation is positive but statistically insignificant at $10 \%$ significance level. It means that a one percent change in exchange rate will raise market index return of $0.15 \%$. And, the short-run impact of inflation rate on the KSE-100 index is although positive but statistically insignificant.

The last term in the Table $8\left(\mathrm{ECM}_{\mathrm{t}-1}\right)$ is the one period lag error of ECM given in equation 8 , and is called the equilibrium residual of one period lag. This term is also known as the ECT that directs the macroeconomic variables of the system to reinstate back to original equilibrium position, i-e. Actually, it corrects the disequilibrium of the system. The sign before omega $(\omega)$ or the sign of ECT term should be expected negative after estimating equation 8 . Its value tells us at what rate or speed it corrects the preceding period deviation of the given system. When ' $\omega$ ' is significant and having negative sign, it corroborates that there exists a long-run equilibrium relations among all economic variables declared in equation 8 . The result confirms the negative sign of ECMt-1 (lagged ECM) and is found high statistically significant at the $1 \%$ level of significance which gives validity to the existence of equilibrium linkage among the particular macro variables. Nevertheless, the speed of adjustment from prior year's disequilibrium in stock market return is $46.53 \%$ annually.

\subsection{Recursive Residuals Testing}

This section explains a figure of the recursive residuals about the straight zero line. In the plot, plus and minus two S. Es (standard errors) are too revealing at each point. Residuals exterior the S.E bands advocate instability in the parameter estimates of the equation. The goodness of fit for the ARDL specification is inspected via stability tests, e.g. CUSUM (cumulative sum of recursive residuals) and 
CUSUMSQ (cumulative sum of squares of recursive residuals), developed by Brown, Durbin and Evans [64]. These diagnostic statistics were applied to analyze the stability of short run plus long run parameter estimates. The CUSUM statistic is given in equation (9) as under:

$$
\operatorname{CUSUM}_{t}=W_{t}=\sum_{r=k+1}^{t} \frac{w_{r}}{s_{r}}
$$

Where, $\mathrm{W}=$ the recursive residual, $\mathrm{s}=\mathrm{S}$.E of the regression fitted to all $\mathrm{T}$ sample size, $\mathrm{t}=\mathrm{k}+1, \ldots, \mathrm{T}$

If the $\beta$ vector remains constant, then $C U S U M_{t}$ has zero mean [i-e. $\mathrm{E}\left(\mathrm{W}_{\mathrm{t}}\right)=0$ ] and variance that is proportional to $\mathrm{t}-\mathrm{k}-1$. But if $\beta$ vector doesn't remain constant, CUSUM $_{t}$ will incline to diverge from the mean line. Similarly, the CUSUMSQ statistic is given in equation (10) as under:

$$
\operatorname{CUSUMS}_{t}=S_{t}=\frac{\sum_{r=k+1}^{t} w_{r}{ }^{2}}{\sum_{r=k+1}^{T} w_{r}{ }^{2}}
$$

If the parameters remain constant, then the expected value of ' $\mathrm{S}$ ' will be as,

$E\left(S_{t}\right)=(t-k) /(T-k)$ which goes from 0 at $\mathrm{t}=\mathrm{k}$ to one at $\mathrm{t}=\mathrm{T}$.

Pesaran et al. [54,55] advocated that both statistics are suitable in checking for stability of parameters in such kind of models. The plot of both CUSUM and CUSUMSQ is significant at 5\% significance level indicating the parameter or variance stability. These both stability diagnostic tests were used to check for the stability of short-run and long-run parameter estimates. For this reason, both the stability tests have been conducted and the outcomes are given in Figure 2 and Figure 3 below. The plot of the CUSUM test shows that the residuals are beyond the red extreme lines, signifying that our model is not stable which means that the dependent variable is not stable. Conversely, the plot of the CUSUMSQ test stays within two polar bounds at the $5 \%$ significance level, confirming that the selected time series model is stable structurally.

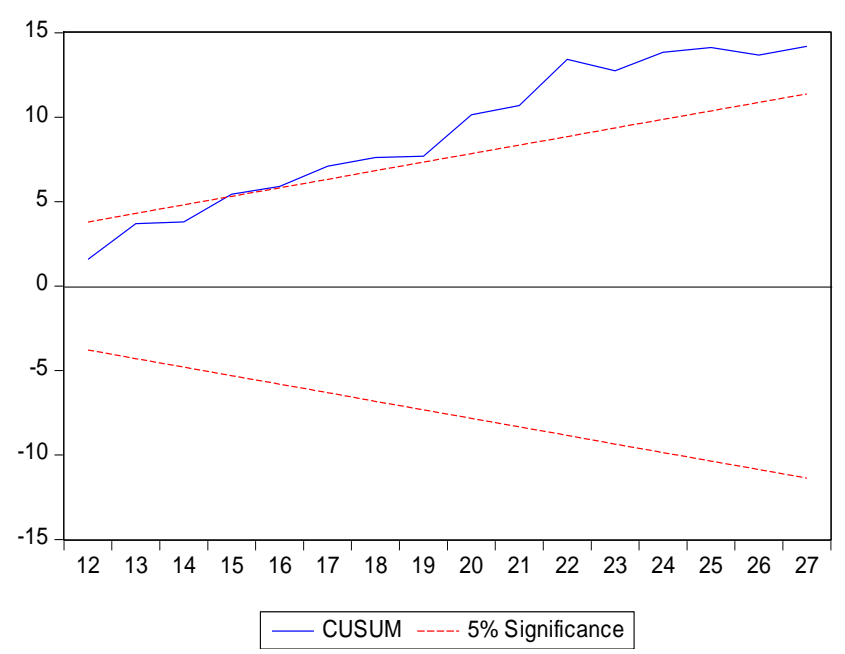

Note: The straight line symbolizes critical bounds at $5 \%$ level of significance for each plot.

Figure 2. Plot of the CUSUM test

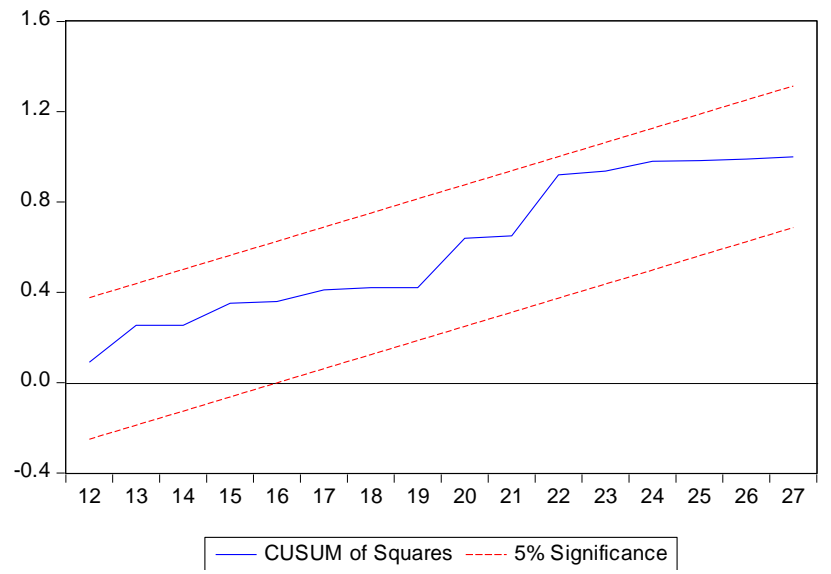

Note: The straight line symbolizes critical bounds at 5\% level of significance for each plot.

Figure 3. Plot of the CUSUMSQ test

\subsection{Other Diagnostics Tests}

Besides the recursive residual statistics, other relevant diagnostic tests have also been applied to the model for checking its strength, suitability and validity.

\subsubsection{Testing for Serial Correlation}

Autocorrelation or serial correlation is normally found in the time series dataset and is regarded as the problem of time series data. There are many tests in the literature such as the Durbin-Watson (D-W) test, Durbin's $h$ test, Breusch-Godfrey LM test, etc. which are applied to check for serial correlation. The Breusch-Godfrey LM test is the most recognized tests for checking the presence of serial correlation (for higher order) as other alternative tests carries several drawbacks. For example, (i) the D-W test may provide inconclusive outcomes; (ii) this test is not practical when a lagged dependent variable is there; and (iii) this test doesn't take into account higher orders (two or more lags) of autocorrelation. Due to such reasons, Breusch and Godfrey [65] introduced an LM test (the Lagrange Multiplier) which we have applied in this study.

$H_{0}$ : Residuals are not serially correlated (no autocorrelation)

$H_{1}$ : Residuals are serially correlated (autocorrelation)

The LM test verdicts are reported in Table 9 which shows that there exist serial correlations up to 2 lags, and hence we reject the null hypothesis of no autocorrelation at the $5 \%$ level of significance as the corresponding probability value of the observed $\mathrm{R}^{2}$ is less than $5 \%$ $(3.01 \%)$.

\subsubsection{Testing for Heteroskedasticity}

In the views of Stock and Watson [66], the presence of heteroscedasticity is more probable to happen within a cross-sectional data. But this conclusion doesn't mean that the problem of heteroscedasticity in time series frameworks is not possible. There are many ways of detecting heteroskedasticity such as the Breusch-Pagan LM test, the Glesjer LM test, the ARCH test, the Harvey-Godfrey LM test, etc., but the most widely accepted one is the White's test [67]. This test has many advantages such as, it doesn't presume any earlier determination of heteroscedasticity 
and it doesn't depend on the normality assumption. The null hypothesis of heteroskedasticity against its alternative hypothesis is:

\section{$H_{0}$ : Errors are homoscedastic (Homoscedasticity) \\ $H_{1}$ : Errors are not homoscedastic (Homoscedasticity)}

The White's test results as shown in Table 10 demonstrates that the corresponding probability value of the observed $\mathrm{R}^{2}$ is $39.33 \%>5 \%$, consequently we can admit our $\mathrm{H}_{0}$, meaning that the proposed model does not have the issue of heteroskedasticity which is a good signal for the model adequacy.

\subsubsection{Testing for Normality}

Testing of hypothesis assumes that the selected model for empirical investigation must be good in the sense that it doesn't violate the basic assumptions of the CLRM (CLRM stands for the Classical Linear Regression Model). Therefore, one such test is the normality test which is used to investigate whether the residuals (or the disturbances) follow normal distribution or not. Since in small sample sizes as the case here, the $t, F$ and chi-square tests necessitate the normality assumption, therefore it is required that this basic assumption be checked formally. For this purpose, the Jarque-Bera test [68] has been applied to check for the following null hypothesis against the alternative hypothesis.

\section{$H_{0}$ : Residuals follow normal distribution}

$H_{1}$ : Residuals are not normal distributed

In the Figure 4, the x-axis plots the residuals and the $y$-axis plots the number of observations taken for this particular study. Application of the J-B test illustrates that the $\mathrm{J}-\mathrm{B}$ statistic is 0.325768 , and its corresponding $\mathrm{p}$-value is 0.849690 (or $84.97 \%$ ) which is more than $5 \%$. Hence, we are not in a position to reject the null hypothesis that the residuals are normally distributed which fulfills the required assumption of a best regression model. And lastly, the statistics shows that the model specification is well constructed which is a good sign for the regression model.

Table 9. Results of the Breusch-Godfrey test

\begin{tabular}{|c|c|c|c|c|}
\hline \multicolumn{7}{|c|}{ Breusch-Godfrey Serial Correlation LM Test } \\
\hline \multicolumn{5}{|c|}{ Second-order Serial Correlation (second-order s.c.)/Lags 2 } \\
\hline F-statistic & 2.726027 & Prob. F $(2,14)$ & 0.1000 & Conclusion \\
\hline Obs* R-squared & 7.007042 & Prob. Chi-Square (2) & 0.0301 & Serial Correlation \\
\hline
\end{tabular}

Source: Outcome from EViews 9

Table 10. Results of the White's test

\begin{tabular}{|l|c|c|c|c|}
\hline \multicolumn{5}{|c|}{ Heteroskedasticity Test: White } \\
\hline F-statistic & 1.016188 & Prob. F (8, 16) & 0.4623 & Conclusion \\
\hline Obs* R-squared & 8.422786 & Prob. Chi-Square (8) & 0.3933 \\
\hline Scaled explained SS & 3.626357 & Prob. Chi-Square (8) & 0.8892 \\
\hline
\end{tabular}

Source: Outcome from EViews 9.

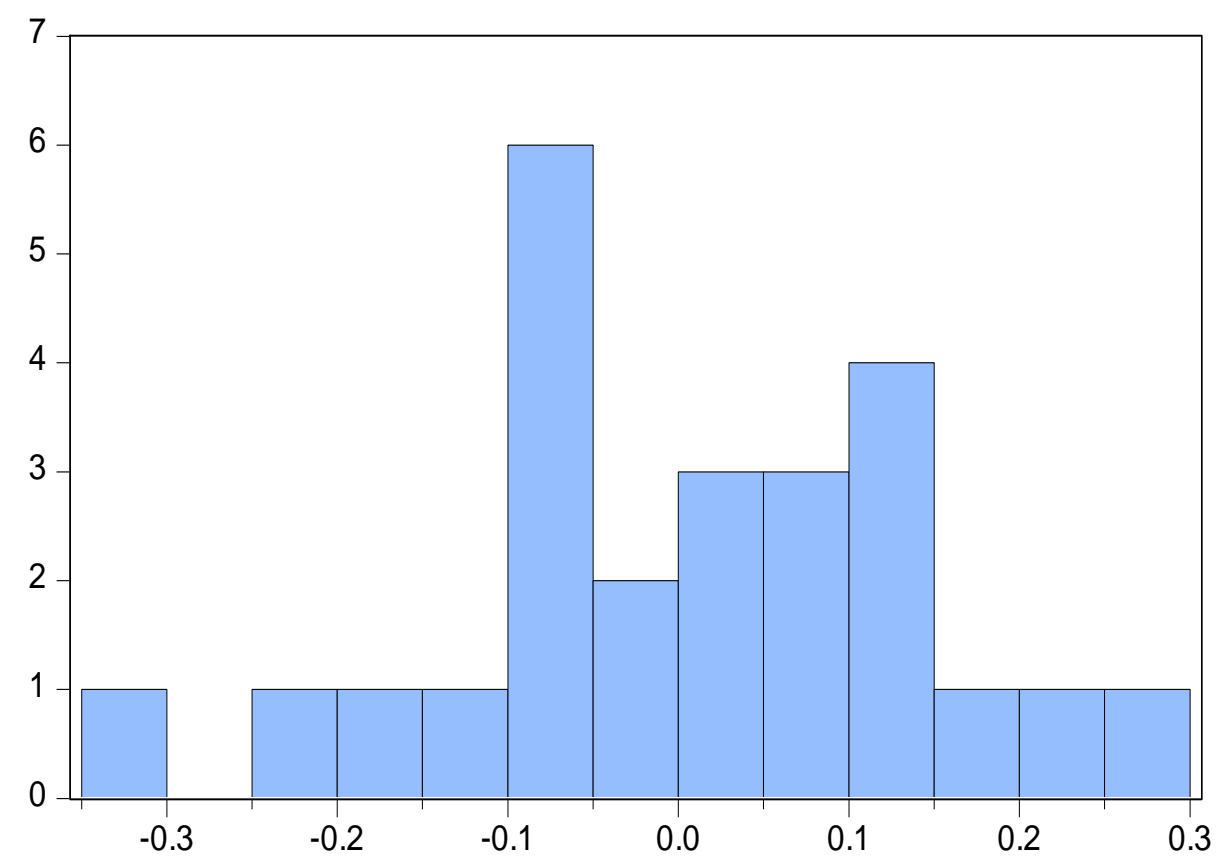

Series: Residuals

Sample 327

Observations 25

Mean

$1.08 \mathrm{e}-15$

Median

0.012594

Maximum

0.262042

Minimum

$-0.341786$

Std. Dev.

0.138001

Skewness

$-0.274901$

Kurtosis

3.102253

Jarque-Bera $\quad 0.325768$

Probability $\quad 0.849690$

Figure 4. Normality of Residuals of a Regression line (Source: Outcome from EViews 9) 


\section{Conclusion and Policy Implications}

In this research paper, we explored empirically the relationship of stock market return with interest rate, exchange rate and inflation rate in Pakistan uses the time series annual data for the period of 1991 to 2017 employing various econometric frameworks. The test results of unit root, illustrate that the economic variables under consideration are mixed stationary. The ARDL procedure to cointegration has been applied to find out the long-run relationship between all the variables that are included in this empirical study. The findings propose that there exists a long-run correlation between interest rate, exchange rate, inflation rate and the KSE-100 index. The results of the selected ARDL model expose that interest rate has a negative and inflation has a positive influence on the PSX index in the long run, and coefficient estimates of both the regressors were found highly statistically significant. Likewise, the exchange rate has a positive, but insignificant impact on the market index in the long-run.

The estimated error correction coefficient of the ARDL procedure signifies that about $46.53 \%$ disequilibrium of the KSE-100 index from its long-run equilibrium path is corrected per annum in the short-run. The results of the CUSUMSQ test suggest that the incorporated model is stable structurally. Similarly, other diagnostics passes the short run model as a best regression model.

Based on the above empirical results, we recommend some policy steps in order to boost the financial sector of Pakistan. The healthy stock market can be encouraged by reducing further the bank rate by the regulatory authority of the monetary policy of the State Bank of Pakistan. The use of bank rate in stimulating PSX market is not receptive to the inflation rate. High bank rates were helpful in discouraging the higher economic growth, whereas the low bank rate would encourage stock market financial activity. Similarly, the reduction in bank rate has a positive impact on the inflation rate of the country. During the periods of higher bank rate, the inflation rate was also higher, and vice versa. Therefore, to curb with the highest inflation rates in the future the monetary authorities need to reduce the bank rate. Besides, the regulatory authorities need to prepare such policies which bring new investors into the stock market for business and will have accordingly favorable effect on the PSX market. If the stock market becomes well-developed, the depreciation of the exchange rate will be automatically stable. The results of this study also help foreign investors to consider the volatility of the PSX market into concern while decision making to invest here since the stock market volatility brings change in exchange rates so foreign investors can also foresee their exchange risk on account of volatility of stock returns.

\section{References}

[1] Horne, J. C. V., Wachowics, J. J. M. (2008), "Fundamentals of Financial Management", $13^{\text {th }}$ Edition, Pearson Education Limited, England.

[2] Akhtar, D. S. (2006), "Pakistan's Financial Services Sector - A Future Prospective", Statistics Department, State Bank of Pakistan, pp. 1-9.
[3] Tripathi, V., Seth, R. (2014), "Stock Market Performance and Macroeconomic Factors: The Study of Indian Equity Market", Global Business Review, Vol. 15, Issue 2, pp. 291-316.

[4] Ahmad, M. I., Rehman, R., Raoof, A. (2010), "Do Interest Rate, Exchange Rate effect Stock Returns? A Pakistani Perspective", International Research Journal of Finance and Economics, Issue 50, pp. 146-150.

[5] Muktadir-al-Mukit, D. (2012), "Effects of Interest Rate and Exchange Rate on Volatility of Market Index at Dhaka Stock Exchange", Journal of Business and Technology (Dhaka), Vol. 7, Issue 2, pp. 1-18.

[6] Kutty, G. (2010), "The Relationship between Exchange Rates and Stock Prices: The Case of Mexico", North American Journal of Finance and Banking Research, Vol. 4, Issue 4, pp. 1-12.

[7] Abraham, T. W. (2011), "Stock Market Reaction to Selected Macroeconomic Variables in the Nigerian Economy", CBN Journal of Applied Statistics, Vol. 2, Issue 1, pp. 61-70.

[8] Aslam, W. (2014), "Relationship between Stock Market Volatility and Exchange Rate: A Study of KSE", Journal of Public Administration, Finance and Law, Issue 5, pp. 62-72.

[9] Ihsan, A., Baloch, Q. B., Kakakhel, S. J. (2015), "Relationship between Exchange Rates and Stock Market Index: Evidence from the Pakistani Stock Market", Abasyn Journal of Social Sciences, Vol. 8, Issue 1, pp. 17-36.

[10] Janjua, M. A (2007), “Pakistan' s External Trade: Does Exchange Rate Misalignment Matter for Pakistan?", The Lahore Journal of Economics, Vol. 12, Issue Special Edition, pp. 126-152.

[11] Hyder, Z., Mahboob, A. (2006), "Equilibrium Real Effective Exchange Rate and Exchange Rate Misalignment in Pakistan", SBP' s Research Bulletin, Vol. 2, Issue 1, pp. 237-263.

[12] Uwubanmwen, D. A., Eghosa, I. L. (2015), "Inflation Rate and Stock Returns: Evidence from the Nigerian Stock Market", International Journal of Business and Social Science, Volume 6, Issue 11, pp. 155-167.

[13] Pakistan, Government of (various issues) Pakistan Economic Survey, Ministry of Finance, Government of Pakistan, Islamabad.

[14] Joseph, N. L., Vezos, P. (2006), "The Sensitivity of US Bank' s Stock Returns to Interest Rate and Exchange Rate Changes", Managerial Finance, Vol. 32, Issue 2, pp. 182-199.

[15] Schwert, G. W. (1981), "The Adjustment of Stock Prices to Information about Inflation", The Journal of Finance, Vol. 36, Issue 1, pp. 15-29.

[16] Fama, E. F. (1981), "Stock returns, real activity, inflation and money", American Economic Review, Vol. 71, Issue 4, pp. 545565.

[17] Pearce, D. K., Roley, V. V. (1985), "Stock Prices and Economic News", The Journal of Business, Vol. 58, Issue 1, pp. 49-67.

[18] Hardouvelis, G. A. (1987), "Macroeconomic Information and Stock Prices", Journal of Economics and Business, Vol. 39, pp. 131-140.

[19] Modigliani, F. (1971), "Monetary Policy and Consumption: Linkages via Interest Rate and Wealth Effects in the FMP Model, Consumer Spending and Monetary Policy: The Linkages", Federal Reserve Bank of Boston Conference Series, Conference Series No. 5, June 1971.

[20] Mishkin, F. (1977), "What Depressed the Consumer? The Household Balance Sheet and the 1973-1975 Recession", Brookings Papers on Economic Activity, Vol. 1, pp. 123-164.

[21] Fama, E. F., Schwert, G. W. (1977), "Asset Returns and Inflation", Journal of Financial Economics, Vol. 5, pp. 115-146.

[22] Muktadir-al-Mukit, D. (2013), "The Effects of Interest Rates Volatility on Stock Returns: Evidence from Bangladesh", International Journal of Management and Business Research, Vol. 3, Issue 3, pp. 269-279.

[23] Kasman, S. (2003), "The Relationship Between Exchange Rates and Stock Prices: A Causality Analysis", DokuzEylul Institute for Social Sciences, Vol. 5, Issue 2, pp. 70-79.

[24] Nath, G. C., Samanta, G. P. (2003), "Relationship Between Exchange Rate and Stock Prices in India - A Empirical Analysis", pp. 1-11.

[25] Mlambo, C., Marezda, A., Sibanda, K. (2013), "Effects of Exchange Rate Volatility on the Stock Market: A Case Study of South Africa", Mediterranean Journal of Social Sciences, Vol. 4, Issue 14, pp. 561-570.

[26] Bhat, K. U., Shah, S. Z. A. (2015), "Empirical Investigation of the Relationship between Exchange Rate Movements and Stock 
Market Volatility in the Context of Pakistan", Pakistan Business Review, pp. 744-758.

[27] Poornima, D. S., Ganeshwari, M. (2016), "Relationship between Exchange Rates and Stock Market Index: Evidence from the Indian Stock Market", International Journal of Science and Research (IJSR), Vol. 5, Issue 10, pp. 16-18.

[28] Hamrita, M. E., Abdallah, N. B., Ammou, S. B. (2009), "The Multi-Scale Interaction between Interest Rate, Exchange Rate and Stock Price", MPRA, Paper No. 18424, Posted 8, pp. 1-11.

[29] Mukherjee, T. K., Naka, A. (1995), "Dynamic Relations between Macroeconomic Variables and the Japanese Stock Market: An Application of a Vector Error Correction Model", Journal of Financial Research, Vol. 18, Issue 2, pp. 223-237.

[30] Limpanithiwat, K., Rungsombudpornkul, L. (2010), "Relationship between Inflation and Stock Prices in Thailand", Master Thesis in Finance, Umea School of Business, UMEA University, Sweden, pp. 1-60.

[31] Ibrahim, T. M., Agbaje, O. M. (2013), "The Relationship between Stock Return and Inflation in Nigeria", European Scientific Journal, Vol. 9, Issue 4, pp. 146-157.

[32] Saleem, F., Zafar, L., Rafique, B. (2013), "Long Run Relationship between Inflation and Stock Return: Evidence from Pakistan", Social Sciences and Humanities (Part-II), Vol. 4, Issue 2, pp. 407-415.

[33] Solnik, B. (1987), "Using Financial Prices to Test Exchange Rate Models: A Note", The Journal of Finance, Vol. 42, Issue 1, pp. 141-149.

[34] Hasan, A., Javed, M. T. (2009), "Macroeconomic Influences and Equity Market Returns: A Study of an Emerging Equity Market", Journal of Economics and Economic Education Research, Vol. 10, Issue 2, pp. 47-68.

[35] Geetha, C., Mohidin, R., Chandran, V. V., Chong, V. (2011), "The Relationship between Inflation and Stock Market: Evidence from Malaysia, United States and China", International Journal of Economics and Management Sciences, Vol. 1, Issue 2, pp. 1-16.

[36] Pakistan, KHI Stocks, Indices Achieves, KSE-100 Index, Pakistan Stock Exchange Limited (PSX), August 08, 2017. http://www.khistocks.com/data-archives/index-archives.html.

[37] Pakistan, Statistics and DWH Department \& Domestic Markets and Monetary Management Department \& External Relations Department \& Monetary Policy Statement, State Bank of Pakistan (2016, 2017), Islamabad.

[38] Rabia, N., Khakan, N. (2015), "Impact of Macro Variables on Karachi Stock Exchange", Journal of Tourism and Hospitality, Vol. 4, Issue 4, pp. 1-5.

[39] Sichoongwe, K. (2016), "Effects of Exchange Rate Volatility on the Stock Market: The Zambian Experience", Journal of Economics and Sustainable Development, Vol. 7, Issue 4, pp. 114-119.

[40] Kennedy, K., Nourizad, F. (2016), "Exchange rate volatility and its effect on stock market volatility", International Journal of Human Capital in Urban Management (IJHCUM), Vol. 1, Issue 1, pp. $37-46$.

[41] Cameron, S. (1994), "A review of the econometric evidence on the effects of capital punishment”, Journal of Socio-Economics, Vol. 23, Issue 1-2, pp. 197-214.

[42] Ehrlich, I. (1975), "The deterrent effect of capital punishment - A question of life and death", American Economic Review, Vol. 65, Issue 3, pp. 397-417.

[43] Ehrlish, I. (1996), "Crime, Punishment and the Market for Offences", Journal of Economic Perspectives, Vol. 10, Issue 1, pp. 43-67.

[44] Aggarwal, R. (1981), "Exchange Rates and Stock Prices: A Study of the U.S. Capital Markets under Floating Exchange Rates", Akron Business and Economic Review, Vol. 12, pp. 7-12.

[45] Smith, C. (1992), "Stock Market and Exchange Rate: A Multicountry Approach", Journal of Macroeconomics, Vol. 14, Issue 4, pp. 607-629.

[46] Sabri, N. R. (2004), "Stock Return Volatility and Market Crisis in Emerging Economics", Review of Accounting and Finance, Vol. 3, Issue 3, pp. 59-83.

[47] Soenen, L. A., Hennigar, E. S. (1988), “An Analysis of Exchange Rates and Stock Prices: the U.S. Experience between 1980 and 1986", Akron Business and Economic Review, Vol. 19, pp. 7-16.

[48] Granger, C. W. J., Huang, B., Yang, C. W. (1998), “A Bivariate Causality between Stock Prices and Exchange Rates: Evidence from the Recent Asia Flu", Unpublished Work, Department of Economics, University of California, San Diego.
[49] Yusuf, M. M., Rahman, H. A. (2012), "Causality Effect between Equity Market and Exchange Rate Volatility in Malaysia", International Proceedings of Economics Development and Research (IPEDR), Vol. 55, Issue 22, pp. 109-114.

[50] Ma, C. K., Kao, G. W. (1990), “On Exchange Rate Changes and Stock Price Reactions", Journal of Business Finance and Accounting, Vol. 17, Issue 3, pp. 441-449.

[51] Beirne, J., Caporale, G. M., Spagnolo, N. (2009), "Market, Interest Rate and Exchange Rate Risk Effects on Financial Stock Returns: A GARCH-M Approach", Quantitative and Quantitative Analysis in Social Sciences, Vol. 3, Issue 2, pp. 44-68.

[52] Pesaran, M. H., Pesaran, B. (1997), "Working with Microfit 4.0: interactive Econometric Analysis", Oxford: Oxford University Press, 1997.

[53] Pesaran, M. H., Shin, Y. (1999), “An autoregressive distributed lag modelling approach to cointegration analysis", In Econometrics and Economic Theory in the 20th Century: The Ragner Frisch Centennial Symposium, Ch. 11, Cambridge University Press, Cambridge.

[54] Pesaran, M. H., Shin, Y., Smith, R. J. (2000), "Structural Analysis of vector error correction model with exogenous $I(1)$ variables", Journal of Econometrics, Vol. 97, Issue 2, pp. 293-343.

[55] Pesaran, M. H., Shin, Y., Smith, R. J. (2001), "Bound testing approaches to the analysis of level relationships", Journal of Applied Econometrics, Vol. 16, Issue 3, pp. 289-326.

[56] Haug, A. A. (2002), "Temporal Aggregation and the Power of Cointegration Tests: a Monte Carlo Study", Oxford Bulletin of Economics and Statistics, Vol. 64, Issue 4, pp. 399-412.

[57] Laurenceson, J., Chai, J. C. H. (2003), "Financial Reforms and Economic Development in China", Cheltenham, UK, Edward Elgar, pp. 1-28.

[58] Nkoro, E., Uko, A. K. (2016), "Exchange Rate and Inflation Volatility and Stock Prices Volatility: Evidence from Nigeria, 1986-2012”, Journal of Applied Finance and Banking, Vol. 6, Issue 6, pages 4

[59] Turner, P. (2006), "Response surfaces for an F-test for cointegration", Applied Economics Letters, Vol. 13, Issue 8, pp. 479-482.

[60] Masih, A., Masih, R. (1997), “On the temporal causal relationship between energy consumption, real income, and prices: Some new evidence from Asian-energy dependent NICs Based on a multivariate cointegration/vector error correction approach", Journal of Policy Modelling, Vol. 19, Issue 4, pp. 417-440.

[61] Ouattara, B. (2004), "The Impact of Project Aid and programme Aid Inflows on Domestic Savings: a Case Study of Cote d' Ivoire", School of Economic Studies, University of Manchester, UK, pp. 1-12.

[62] Gujarati, D. N. (2004), "Basic Econometrics", 4th Edition, The McGraw-Hill Companies.

[63] Bahmani-Oskooee, M., Bohl, M. T. (2000), "German monetary unification and the stability of the German M3 money demand function", Economics Letters, Vol. 66, Issue 2, pp. 203-208.

[64] Brown, R. L., Durbin, J., Evans, J. M. (1975), "Techniques for Testing the Constancy of Regression Relationships over Time", Journal of Royal Statistical Society. Series B (Methodological), Vol. 37, Issue 2, pp. 149-192.

[65] Breusch, T. (1978), "Testing for Autocorrelation in Dynamic Linear Models", Australian Economic Papers, Vol. 17, pp. 334-355.

[66] Stock, J. H., Watson, M. W. (2003), "Introduction to Econometrics", Illustrated Edition, Addison Wesley, Boston, Mass, London.

[67] White, H. (1980), “A Heteroscedasticity-Consistent Covariance Matrix Estimator and a Direct Test for Heteroscedasticity", Econometrica, Vol. 48, pp. 817-838

[68] Jarque, C. M., Bera, A. K. (1987), "A Test for Normality of Observations and Regression Residuals", International Statistical Review, Vol. 55, pp. 163-172.

[69] Mbulawa, S. (2015), "Effect of Macroeconomic Variables on Economic Growth in Botswana", Journal of Economics and Sustainable Development, Vol. 6, Issue 4, pp. 68-78.

[70] Mbulawa, S. (2015), "Stock Market Performance, Interest Rate and Exchange Rate Interactions in Zimbabwe: A Cointegration Approach", International Journal of Economics, Finance and Management, Vol. 4, Issue 2, pp. 77-88.

[71] Pakistan, Price Statistics (2017), Statistics House, Pakistan Bureau of Statistics, Islamabad, Government of Pakistan. 